1 | Suffice et al.

1 Pauline Suffice

2 Université du Québec en Abitibi Témiscamingue

3 445, boulevard de l'Université

4 Rouyn-Noranda (Québec) J9X 5E4

5 (819) 860-3346

6 pauline.suffice@uquat.ca

RH: Suffice et al. · Fisher and American Marten Quebec

\title{
Habitat, Climate, and Fisher and Marten Distributions
}

PAULINE SUFFICE, ${ }^{1}$ Université du Québec en Abitibi-Témiscamingue, 445 boulevard de l'Université, Rouyn-Noranda, Québec J9X 5E4, Canada

MARIANNE CHEVEAU, Ministère des Forêts, de la Faune et des Parcs, Gouvernement du Québec, Direction générale de la gestion de la faune et des habitats, 880, chemin Sainte-Foy, 2e étage, Québec, Québec G1S 4X4, Canada

LOUIS IMBEAU, Université du Québec en Abitibi-Témiscamingue, 445 boulevard de l'Université, Rouyn-Noranda, Québec J9X 5E4, Canada

MARC J. MAZEROLLE, Centre d'étude de la forêt, Département des sciences du bois et de la forêt, Pavillon Abitibi-Price, 2405 rue de la Terrasse, Université Laval, Québec, Québec G1V0A6, Canada

HUGO ASSELIN, Université du Québec en Abitibi-Témiscamingue, 445 boulevard de l'Université, Rouyn-Noranda, Québec J9X 5E4, Canada

PIERRE DRAPEAU, Université du Québec à Montréal, Département des sciences biologiques, 141, Avenue du Président-Kennedy, Montréal, Québec H2X 1 Y4, Canada

$1 \quad$ Email : pauline.suffice@,uqat.ca 
2 | Suffice et al.

28 ABSTRACT Since the mid-twentieth century, fisher populations (Pekania pennanti)

29 increased in several eastern jurisdictions of North America, particularly in the northern

30 part of the species' range. Changes in fisher distribution have led to increased overlap

31 with the southern portion of the range of American marten (Martes americana), whose

32 populations may be locally declining. This overlap occurs particularly in habitats

33 undergoing natural and anthropogenic modification. The objective of our study was to

34 determine the respective effects of habitat changes and climatic conditions on fisher and

35 marten populations in Quebec, Canada, based on trapper knowledge. We analyzed annual

36 fisher and marten harvest (number of pelts sold/100 $\mathrm{km}^{2}$ ) between the 1984-1985 and

$37 \quad 2014-2015$ trapping seasons using linear mixed models. Fisher harvest increased with the

38 increased abundance of mixed forests $>12 \mathrm{~m}$ tall, resulting from decades of forest

39 harvesting. Fisher harvest decreased with increasing spring rains, which can affect

40 survival when rearing young. Marten harvest decreased with increasing winter rains,

41 which lower thermoregulation capacity and hamper movements by creating an ice crust

42 on the snowpack, reducing access to subnivean areas. Decline in marten harvest during

43 the 30-year study period coincided with an increase in fisher harvest, suggesting possible

44 interspecific competition. Results highlight that managers should strive to maintain

45 mixedwood stands taller than $12 \mathrm{~m}$ to maintain high quality habitat for fishers. Our study

46 confirms the importance of working with trappers to assess furbearing population trends

47 in response to habitat changes and climatic conditions.

48

49 KEY WORDS American marten, fisher, forest harvesting, furbearer management, 50 mixedwood forest, mustelids, pelt sales, rain. 
3 | Suffice et al.

52 Unregulated harvest and habitat loss led to declines in populations of several forest

53 carnivores in North America (Tapper and Reynolds 1996, Krohn 2012). Fisher (Pekania

54 pennanti) and American marten (Martes americana) are 2 North American mustelids

55 whose populations decreased because of overexploitation for fur and loss of habitat due

56 to timber harvesting (Powell et al. 2003, Williams et al. 2007). After a decline during the

57 mid-nineteenth century, fisher populations have rebounded since the mid-twentieth

58 century in the eastern portion of the species' range, particularly in the northeastern United

59 States, and in the Canadian provinces of Ontario and Quebec (Bowman et al. 2006,

60 Lancaster et al. 2008, Krohn 2012, Lewis et al. 2012, LaPoint et al. 2015). Fisher

61 recovery is due to translocation efforts, natural recolonization (Carr et al. 2007a, Stewart

62 et al. 2017), habitat modification, and beneficial effects from climate change (Lancaster

63 et al. 2008). In some cases, fisher re-establishment could result in declines in marten

64 populations due to interspecific competition (Krohn et al. 1997, Fisher et al. 2013,

65 Manlick et al. 2017). Because of its larger size, fisher is a dominant competitor of marten

66 (Krohn et al. 1997). Interference competition from fishers could have forced martens to

67 leave shared territories (Tannerfeldt et al. 2002). Marten populations, however, appear to

68 be recovering in several parts of eastern North America shared with fisher (Aylward et al.

69 2018) but not in Quebec. Fisher harvest in Quebec is generally increasing, whereas that

70 of martens is decreasing (Poulin et al. 2006, Suffice et al. 2017, Lavoie et al. 2019).

71 According to Poulin et al. (2006), increased fisher harvesting in Quebec is more strongly

72 associated with population increases than with increased trapping pressure. 
4 | Suffice et al.

Anthropogenic disturbance and climatic conditions can upset established

74 equilibria and induce changes in habitat use by species (Graham and Grimm 1990, Lodge

75 1993). North American forests have been affected by human activities over recent

76 decades (e.g., agricultural intensification, urbanization, forest logging; Reif 2013, Bridger

77 et al. 2017). Forest logging differs from natural disturbances in terms of frequency,

78 intensity, and spatial extent. It has resulted in younger, more fragmented forests with

79 different tree species composition (Schulte et al. 2007, Boucher et al. 2014, Grondin et al.

80 2018). This in turn increased the number of wildlife species requiring early successional

81 habitat but reduced the number of species requiring mature contiguous forest (Drapeau et

82 al. 2000, Plante et al. 2018). Such modifications in the structure and composition of forest

83 landscapes have a direct effect on habitat availability for mustelids (Buskirk 1992, Payer

84 and Harrison 2005, Spencer et al. 2015).

85 At the population level, fishers are associated with dense forests and high, closed

86 canopies used as resting sites (Buskirk 1992, Powell and Zielinski 1994, Potvin et al.

87 2000, Powell et al. 2003). Large-diameter trees often provide cavities used as refuges by

88 fishers, whereas conifers intercept snow, reducing accumulation on the ground and

89 facilitating fisher movement (Powell et al. 2003). The absence of important predators in

90 northern portions of the fisher's range could explain the use of more open land cover

91 types than elsewhere in its distribution (Wengert et al. 2014), particularly along forest

92 edges adjacent to agricultural fields and in younger forests (Suffice et al. 2017). Fishers

93 also find important food sources in such cover types: snowshoe hare (Lepus americanus)

94 and cervid carcasses (Potvin et al. 2005). In contrast, martens are more dependent upon

95 protective cover from predation and inclement weather (Powell et al. 2003). 
5 | Suffice et al.

96 Consequently, martens occupy mature forests with dense cover and complex structure

97 close to ground level, where they hunt for small mammals (Buskirk and Ruggiero 1994,

98 Bissonette et al. 1997, Chapin et al. 1998, Potvin et al. 2000, Fuller et al. 2005). Recovery

99 of marten populations in the northeastern United States coincides with the re-

100 establishment of older, larger forest patches (Aylward et al. 2018). The association

101 between marten and old, dense coniferous stands, however, is not exclusive (Cheveau et

102 al. 2013). For example, snowshoe hares, which are more important prey for marten in the

103 eastern than in the western portion of its range, are associated with early successional

104 hardwood stands (Potvin et al. 2000).

105

Altered snow conditions in recent years have also directly affected the northern

106 distribution of mesocarnivores (including fisher and marten) with differing effects

107 depending upon species (Pozzanghera et al. 2016). The energy expenditure associated

108 with animal movement through snow varies according to snow depth and the lift it

109 provides, together with the speed of the individual's movements (Crête and Larivière

110 2003). Snow conditions particularly affect fisher dispersal (Raine 1983, Krohn et al.

111 2005, Carr et al. 2007b, Garroway et al. 2011, Bertrand et al. 2017) because they are

112 larger and heavier than martens and exert greater foot loading $\left(18.2-32.0 \mathrm{~g} / \mathrm{cm}^{2} \mathrm{vs} .9 .1-\right.$

$11312.2 \mathrm{~g} / \mathrm{cm}^{2}$ ). Compared to martens, movements of fishers tend to be more strongly

114 constrained by deep, uncompacted snow (Kilpatrick and Rego 1994, Krohn et al. 2005).

115 Presence of an ice crust resulting from freeze-thaw events increases snow lift, which can

116 facilitate fisher movements (Suffice et al. 2017). Conversely, the ice crust limits

117 subnivean access (Berteaux et al. 2017), which is the principal medium through which

118 martens move (Raine 1987, Sherburne and Bissonette 1994, Krohn et al. 2005). Climate 
6 | Suffice et al.

119 change could simultaneously be a challenge to marten populations at the southern edge of 120 the species' distribution (Lavoie et al. 2019), and benefit fisher at the northern edge of its

121 distribution (Manlick et al. 2017). Understanding the influences on wildlife distribution is

122 important to decipher the role of human activities and establish best practices for timber

123 and wildlife management considering climate change.

124 In a previous study documenting the knowledge of Quebec trappers about fisher

125 and marten habitat use (Suffice et al. 2017), lack of exclusivity of both species to

126 coniferous forests was highlighted, although marten was more closely associated with

127 coniferous forests than fisher. Fisher apparently also uses open environments, including

128 agricultural fields and younger forests. Moreover, climate change increases the frequency

129 of freeze-thaw events that cause the formation of an ice crust on snow surface, favoring

130 fisher movements and accessibility to new territories. According to trappers, fisher is less

131 affected by forest management than marten, and the species also seems to benefit to a

132 greater extent from the effects of climate change. The increase in winter rainfall

133 frequency and forest cover changes have been identified by trappers as the major factors

134 that may explain changes in fisher and marten abundance (Suffice et al. 2017). Our

135 objective was to quantify the respective effects of habitat change and climatic conditions

136 on the numbers of fishers and martens trapped in Quebec between the 1984-1985 and

137 2014-2015 trapping seasons. We tested hypotheses developed using a combination of

138 local knowledge from trappers and a literature review (Table 1). We predicted that fisher

139 and marten would be more abundant in forests with complex internal structure, regardless

140 of the canopy dominance. We predicted that fisher would use more open stands and 
7 | Suffice et al.

141 agricultural fields than marten. We predicted that rainfall on snow would promote fisher

142 movement and survival but reduce marten survival.

\section{STUDY AREA}

144 The province of Quebec is divided into 96 fur-bearing animal management units

145 (FAMUs; Fig. 1). Our analysis included 71 FAMUs, ranging in size from $169 \mathrm{~km}^{2}$ to

$14623,820 \mathrm{~km}^{2}$, representing 346,750 $\mathrm{km}^{2}$ from 1984 to 2015 . We excluded territories above

$14751^{\circ} \mathrm{N}$, which have not been extensively exploited for fur, and Anticosti Island, where

148 fishers and martens are absent. We also had to remove FAMUs corresponding to beaver

149 (Castor canadensis) reserves where furbearer exploitation is exclusive to Indigenous

150 people and where data on the number of annual trappers are not recorded.

151 Tree species included maple (Acer spp.), birch (Betula spp.), poplar (Populus

152 spp.), balsam fir (Abies balsamea), pine (Pinus spp.), and spruce (Picea spp.). We

153 divided FAMUs into 3 zones that differed in logging intensity. First, the southernmost

154 zone included areas in the sugar maple (Acer saccharum)-bitternut hickory (Carya

155 cordiformis) and sugar maple-basswood (Tilia americana) bioclimatic domains

156 (hardwood forests, 11 FAMUs). These forests were mostly on private land and had been

157 relatively untouched by timber exploitation compared to those in the other zones. Second,

158 the intermediate zone included areas in the sugar maple-yellow birch (Betula

159 alleghaniensis) and balsam fir-yellow birch domains (mostly mixed forests, 35 FAMUs),

160 which have been mainly managed through partial cuts. Third, the northernmost zone

161 included areas in the balsam fir-paper birch (Betula papyrifera) and black spruce (Picea

162 mariana)-feather moss domains (mostly coniferous forests, 25 FAMUs), mainly

163 managed with clearcuts. 
8 | Suffice et al.

Land use in the study area consisted mainly of forest harvesting and agriculture, 174 in May.

175 and to a lesser degree, urban development. The study area was flat (mostly within $500 \mathrm{~m}$ above sea level) except for a few mountainous areas with the highest peak reaching 1,181 m above sea level. The study area had a cold and wet continental climate. On average, temperature remained near or below the freezing point from November to March, but typically exceeded $10^{\circ} \mathrm{C}$ from June to September (climate normals 1981-2010, Gouvernement du Québec 2019). Annual precipitation averaged 1,000 mm, of which about $75 \%$ fell as rain. Average monthly precipitation was $>55 \mathrm{~mm}$. The annual snowfall averaged $275 \mathrm{~cm}$. Snowfall started as early as October, but snow did not significantly accumulate on the ground until November. Snowfall usually ended in April, occasionally

In Québec, fisher and marten can hunt American red squirrel (Tamiasciurus hudsonicus), northern flying squirrel (Glaucomys sabrinus), striped chipmunk (Tamias striatus), snowshoe hare, and gallinaceous birds, including ruffed grouse (Bonasa umbellus) and spruce grouse (Falcipennis canadensis), especially in winter. Other dietary components include carcasses of white-tailed deer (Odocoileus virginianus), North American moose (Alces americanus), and North American beaver. Fisher can hunt larger-sized preys such as muskrat (Ondatra zibethicus), woodchuck (Marmota monax), striped skunk (Mephitis mephitis), and North American porcupine (Erethizon dorsatum). Fisher and marten can also eat wild fruit such as red raspberries (Rubus idaeus) and nuts such as beaked hazelnut (Corylus cornuta). The main predators of marten and fisher are raptors, mostly owls (e.g., great horned owl [Bubo virginianus]), eagles (bald eagle [Haliaeetus leucocephalus], golden eagle [Aquila chrysaetos]), falcons, hawks, and 
9 | Suffice et al.

187 terrestrial large predators, mostly grey wolf (Canis lupus), coyote (Canis latrans), red fox

188 (Vulpes vulpes), and Canada lynx (Lynx canadensis). Bobcat (Lynx rufus) and cougar

189 (Puma concolor) are rare or absent in Québec.

190 METHODS

191 Pelt Sales Data

192 The Quebec Ministry of Forests, Wildlife and Parks (MFFP; Ministère des Forêts, de la 193 Faune et des Parcs) recorded the number of pelts sold in each of the FAMUs since the 194 1984-1985 trapping season (Oct-Mar). Trappers capture martens and fishers using the 195 same devices (i.e., body gripping traps set on a live tree or on a pole; Gouvernement du 196 Québec, and Fédération des trappeurs gestionnaires du Québec 2019). The length of the 197 trapping season remained constant over the study (i.e., Oct-Mar). To account for 198 variation in area among FAMUs, we calculated pelt yield (number of pelts sold/100 $199 \mathrm{~km}^{2}$ )/FAMU/year. Part of the harvest is not traded as raw pelts and can be tanned and 200 processed for crafts. Despite some limitations, we consider that pelt sales data are a 201 reasonable index of harvest that can be used to assess temporal changes in populations of 202 low-density species such as mustelids (Gese 2001, Kawaguchi et al. 2015).

203 All pelt sales in Quebec are supposed to be recorded in a provincial register, 204 including trapping season, FAMU, and trapper certificate number. Interviews with 205 trappers, however, revealed that only part of the harvest is recorded (Suffice et al. 2017).

206 As a result, we treated the number of pelts sold adjusted for trapping effort as an index of 207 population size. We used 2 variables to account for potential variations in trapping effort:

208 the number of trappers that sold $\geq 1$ marten or 1 fisher pelt in a given FAMU in a given 209 year, and the average auction price of a marten pelt in the previous year. 
10 | Suffice et al.

210

211 Between 1984 and 2015, the forests of Quebec were subjected to 3 governmental decadal

212 inventories during 1979-1990 (Ministère de l'Énergie et des Ressources du Québec

213 1984), 1990-2002 (Létourneau et al. 2009), and 2002-2018 (Lemieux et al. 2015). The

214 governmental forest mapping is produced at the stand scale by interpretation of aerial

215 photographs. These inventories make it possible to follow major trends in forest structure

216 and composition. We used maps from the SIFORT (Système d'Information Forestière par

217 Tesselle) database (Pelletier et al. 2007), composed of 14-ha polygons that are each

218 assigned the stand characteristics of the eco-forest map polygon found at its center. It

219 takes approximately 10 years to inventory the entire forest territory of Quebec. Thus, all

220 FAMUs are not inventoried the same year. We matched pelt sales data from each

221 trapping season (1984-2015) in each FAMU with the trends in forest structure and

222 composition that were nearest in time and that covered the largest area of each FAMU.

223 For each FAMU, we calculated the area that was covered by forest and by

224 agriculture as a percentage of area. We grouped forest stands into 6 major forest cover

225 types by combining 2 criteria considered important for mustelids: structure as described

226 from height classes (4-12 m, >12 m) and tree species composition (deciduous, mixed,

227 coniferous; Potvin et al. 2000, Purcell et al. 2012, Cheveau et al. 2013). We considered

228 stands that were $4-12 \mathrm{~m}$ in height to be young forests. Stands taller than $12 \mathrm{~m}$ generally

229 consist of mature and old-growth forests with large-diameter trees, together with

230 moribund and dead trees (snags; downed dead wood), which provide diversity in

231 structures used by fisher and marten. Yet presence of trees taller than $12 \mathrm{~m}$ does not

232 necessarily mean that a stand should be considered mature. Relative contributions of 
11 | Suffice et al.

233 young, mature and old forests in the $>12 \mathrm{~m}$ height class depend on bioclimatic domain

234 and on the dynamics of natural and anthropogenic disturbances. In the hardwood forest

235 zone, very few intact old-growth forests remain (Angers et al. 2005), given that these

236 areas have experienced anthropogenic disturbances such as conversion of forests to

237 agricultural use (Jobin et al. 2003, Domon and Bouchard 2007) or urban development

238 (Domon et al. 2000). Stands taller than $12 \mathrm{~m}$ are more likely to consist of relatively

239 young forests that have only recently reached $12 \mathrm{~m}$, or mature forests that have been

240 disturbed by low-intensity logging or sugar maple syrup production in the past. The

241 mixed forest zone marks the transition between temperate and boreal forests, where

242 stands are mainly harvested by partial cuts. In the coniferous forest zone, prior to the

243 recent deployment of commercial forestry, landscapes were dominated by forests $>100$

244 years old (Bergeron et al. 2006). Consequently, stands that are taller than $12 \mathrm{~m}$ in this

245 zone are mainly mature and old growth.

246 We mapped changes in forest composition and the area of land under agriculture

247 in each FAMU by computing the difference in area of a given cover type between the

248 forest inventories of the 1980s and 2010s. We designated forest stands $4-12 \mathrm{~m}$ tall as

249 being either dominated by deciduous (deciduous 4-12 m), mixedwood (mixedwood 4-12

$250 \mathrm{~m}$ ), or coniferous (coniferous 4-12 m) species. We gave similar designations to stands

$251>12 \mathrm{~m}$ tall (deciduous $>12 \mathrm{~m}$, mixedwood $>12 \mathrm{~m}$, coniferous $>12 \mathrm{~m}$ ).

252 We summarized rainfall abundance to evaluate the potential for ice crust

253 formation on the snow surface. We obtained daily meteorological data with BioSIM

254 11.4.6.0 (Régnière and St-Amant 2007, Régnière et al. 2017). The software interpolates

255 regional temperature and precipitation data for a given location from nearby weather 
12 | Suffice et al.

256 stations, adjusted for differences in elevation, latitude, and longitude using regional

257 gradients. We extracted the data from BioSIM corresponding to the distance-weighted

258 average of the 3 weather stations that were closest to the centroid of each FAMU. We

259 then compiled the data to obtain the sum of rainfall $(\mathrm{mm})$ and the number of days with

260 rainfall for the trapping season (15 Nov-1 Mar); the winter preceding the trapping season

261 (15 Nov-30 Apr), to test for the delayed effect (1-yr lag) of rain on adult survival and

262 reproduction; and the period of cold spring rainfall during the first few weeks of life of

263 young mustelids (15 Mar-30 May, before the trapping season; Macdonald and Newman

264 2002). We calculated cold spring rain based on the number of days when rainfall was

265 greater than the third quartile of the distribution for daily rainfall data $(>1.7 \mathrm{~mm})$, and

266 when the minimum temperature was less than the third quartile of the distribution for

267 daily minimum temperature data $\left(<2.2^{\circ} \mathrm{C}\right)$. We used the same spring period for both

268 species, considering that female fishers and martens give birth in late March or April

269 (Powell et al. 2003). For descriptive purposes, we modeled temporal variation in climatic

270 variables by linear regressions with year as an explanatory variable at the level of each

271 FAMU. We then mapped the estimate of the regression slope of each FAMU to illustrate

272 variations of the climatic variables across years.

\section{Statistical Analyses}

274 We applied a logarithmic transformation to homogenize the variance of fisher and marten

275 yield data (number of pelts sold/100 $\mathrm{km}^{2}$ ). We analyzed changes in yield/FAMU/year

276 using linear mixed models in the nlme package of R 3.4.2 (Pinheiro et al. 2018). We

277 included a random intercept and random year slope for each FAMU in the models. We

278 included the 2 variables in each model to reflect variations in trapping effort: the number 
13 | Suffice et al.

279 of trappers that traded $\geq 1$ marten or fisher pelt in a given year and the average auction

280 price of a marten pelt in the previous year. All models included a continuous first-order

281 autocorrelation structure (CAR1; Pinheiro and Bates 2000) between consecutive

282 observations from a given FAMU to account for the time series structure of the data. We

283 formulated 7 candidate models based on hypotheses derived from interviews with local

284 trappers and from a literature review (Table 1). These hypotheses involved the effects of

285 rain on mustelid mobility and young survival, the importance of forest age and dominant

286 cover type, and the effect of open areas. We added 9 models combining different

287 uncorrelated variables $(|r|<0.7)$ in the analyses: stands $4-12 \mathrm{~m}$ and rain conditions (3

288 models), stands taller than $12 \mathrm{~m}$ and rain conditions (3 models), and agricultural fields

289 and rain conditions ( 3 models), resulting in 16 candidate models. We standardized all

290 numeric variables prior to analysis.

291 We conducted independent analyses for the 3 geographical zones under study. We

292 estimated parameters by maximum likelihood. We used model selection based on the

293 Akaike's Information Criterion for small samples $\left(\mathrm{AIC}_{c}\right)$ to identify the top models

$294\left(\Delta \mathrm{AIC}_{c}<4\right)$ associated with our biological hypotheses (Table 1). We quantified the effect

295 of variables appearing in the top models with multi-model inference using the shrinkage

296 estimator (AICcmodavg package; Burnham and Anderson 2002, Mazerolle 2017). We

297 model-averaged coefficients and predictions across all models.

$298 \quad$ RESULTS

299 During 1984-2015, annual fisher yield averaged $2.31 \pm 2.38$ (SD) individuals $/ 100 \mathrm{~km}^{2}$ in

300 the hardwood forest zone, $1.64 \pm 1.78$ individuals $/ 100 \mathrm{~km}^{2}$ in the mixed forest zone, and

$3010.21 \pm 0.35$ individuals $/ 100 \mathrm{~km}^{2}$ in the coniferous forest zone (Fig. 2). During the same 
14 | Suffice et al.

302 period, mean annual marten yield was $2.86 \pm 5.24$ individuals $/ 100 \mathrm{~km}^{2}$ in the hardwood

303 forest zone, $7.97 \pm 5.50$ individuals $/ 100 \mathrm{~km}^{2}$ in the mixed forest zone, and $7.57 \pm 5.37$

304 individuals/100 $\mathrm{km}^{2}$ in the coniferous forest zone.

305 Habitat and Rain Changes

306 Habitat proportions by FAMU were characteristic of each of the 3 zones (Fig. S1,

307 available online in Supporting Information). The cover of agricultural fields changed very

308 little within FAMUs ( $\bar{X}$ average percent change between the first and the third forest

309 governmental decadal inventories for FAMU area [range of percentage change] = -

$310 \quad 0.72 \%[-5.41 \%-1.27 \%]$; Fig. S2, available online in Supporting Information).

311 Similarly, there were few variations within FAMUs in terms of deciduous stand cover for

312 each height class: $4-12 \mathrm{~m}=-0.98 \%(-9.42 \%-5.34 \%)$ and $>12 \mathrm{~m}=-0.95 \%(-10.13 \%-$

$3135.57 \%$; Fig. S3, available online in Supporting Information). In contrast, the area of

314 mixedwood stands generally increased for both height classes: $3.08 \%$ for $4-12 \mathrm{~m} \mathrm{(-}$

$31510.41 \%-36.19 \%)$ and $3.18 \%$ for $>12 \mathrm{~m}(-10.58 \%-11.84 \%)$. The area of coniferous

316 stands $>12$ m mainly decreased $(-1.44 \%$ [-14.19\% - 13.92\%]), whereas those in the 4-12-

$317 \mathrm{~m}$ height class remained relatively stable $(0.66 \%[-9.57 \%-10.75 \%])$, although there

318 were increases in the northernmost FAMUs. Changes in forest composition and area

319 under agriculture varied across FAMUs, especially in the coniferous forest zone where

320 mean forest age decreased. The proportion of mature forest was higher in the hardwood

321 forest zone. Stand area in the 4-12-m height class declined (Fig. S3), whereas the area of

322 stands $>12 \mathrm{~m}$ increased (Fig. S4, available online in Supporting Information).

323 Number of days with rain and amount of rain that fell during the 3 periods showed

324 inter-annual variations of different amplitudes among zones (Figs. S5, S6, available 
15 | Suffice et al.

325 online in Supporting Information). Variation of rain conditions between 1984 and 2015

326 also varied among FAMUs (Figs. S7, S8, available online in Supporting Information).

327 Over the study period, the number of days with rain during winter increased in the

328 northern and western parts of the study area, whereas it decreased in the southeast.

329 Rainfall increased in most areas, suggesting an increase in days with heavy rains. The

330 number of days with cold rain $\left(>1.7 \mathrm{~mm}\right.$; min. temp $\left.<2.2^{\circ} \mathrm{C}\right)$ increased only in a few

331 areas.

\section{Fisher Yield}

333 Models that included rainfall during the previous winter or cold rain during the previous

334 spring had the most support $\left(0.46<\right.$ Akaike weight $\left.\left[\omega_{i}\right]<0.62\right)$ for all 3 zones (Appendix

335 A). Models that combined the availability of stands $>12 \mathrm{~m}$, with rain during the previous

336 winter $\left(\omega_{\mathrm{i}}=0.62\right)$, cold rain during the previous spring $\left(\omega_{\mathrm{i}}=0.24\right)$, or rain during the

337 trapping season $\left(\omega_{\mathrm{i}}=0.09\right)$ were the most parsimonious for the hardwood forest zone.

338 For the mixed forest zone, the model with only cold rain during the previous spring had

339 twice the weight of the model including cold rain during the previous spring and the

340 cover of agricultural fields $\left(\omega_{\mathrm{i}}=0.46\right.$ vs. $\left.\omega_{\mathrm{i}}=0.24\right)$, and 4 times the weight of models

341 including the availability of stands $4-12 \mathrm{~m}\left(\omega_{\mathrm{i}}=0.11\right)$ or $>12 \mathrm{~m}\left(\omega_{\mathrm{i}}=0.09\right)$. The model

342 that combined the availability of stands $>12 \mathrm{~m}$, with cold rain during the previous spring

343 had $84 \%$ of the weight for the coniferous forest zone $\left(\omega_{\mathrm{i}}=0.84\right)$. All other models had

344 much less support $\left(\Delta \mathrm{AIC}_{c}>4\right)$.

345 Annual fisher yield increased over time in all 3 zones but more so in the mixed

346 forest zone (Table 2; Fig. 3). Annual fisher yield in all 3 zones increased with the number

347 of trappers having sold $\geq 1$ marten or fisher pelt, but the effect was stronger in the 
16 | Suffice et al.

348 hardwood forest zone. Annual fisher yield in all 3 zones decreased with the average

349 selling price of a marten pelt at the auction from the previous year, but the effect was

350 weak. Annual fisher yield in the hardwood and coniferous forest zones increased with the

351 area covered by mixedwood stands $>12 \mathrm{~m}$ (Fig. 4), but there was no similar relationship

352 in the mixed forest zone. Fisher yield in the hardwood and coniferous forest zones

353 decreased despite increases in the area covered by deciduous stands $>12 \mathrm{~m}$. Within mixed

354 and coniferous zones, fisher yield decreased with increases in the number of cold days

355 with rain during the spring preceding the trapping season, but these relationships were

356 weak (Table 2).

357 Marten Yield

358 In the hardwood forest zone, the null model had the greatest weight to explain variation 359 in marten yield (Appendix $\mathrm{B} ; \omega_{\mathrm{i}}=0.25$ ). Models that included cold rain during the spring 360 preceding the trapping season $\left(\omega_{\mathrm{i}}=0.19\right)$, the availability of stands $4-12 \mathrm{~m}\left(\omega_{\mathrm{i}}=0.16\right)$, or 361 both $\left(\omega_{\mathrm{i}}=0.10\right)$ shared the majority of the rest of the weight. Models that included the 362 availability of stands $>12 \mathrm{~m}\left(\omega_{\mathrm{i}}=0.05\right)$, the amount of agricultural fields $\left(\omega_{\mathrm{i}}=0.04\right)$, or 363 rain during the previous winter $\left(\omega_{\mathrm{i}}=0.04\right)$ had weak support. In the mixed forest zone, 364 the model consisting of the amount of agricultural fields and rain during the previous 365 winter had the entire support $\left(\omega_{\mathrm{i}}=1\right)$. In the coniferous forest zone, the top-ranked model 366 included the availability of stands 4-12 $\mathrm{m}$ and rain during the trapping season (Appendix 367 B). This model had 3 times the weight of the second-ranked model (0.57 vs. 0.13), which 368 consisted of the rain during the trapping season. A third model consisting of the amount 369 of agricultural fields and rain during the trapping season had $12 \%$ of the support. Marten 370 yield decreased over time in the hardwood forest and mixed forest zones (Table 3), yet no 
17 | Suffice et al.

371 such relationship was in the coniferous forest zone. Annual marten yield in all 3 zones

372 increased with the number of trappers having sold $\geq 1$ marten or fisher pelt, but the effect

373 was stronger in the mixed and coniferous forest zones (Table 3).

374 Annual marten yield in the mixed and coniferous zones decreased with the

375 average selling price of a marten pelt at the auction from the preceding year (Table 3 ).

376 The price of a marten pelt had a greater effect on annual marten yield than on annual

377 fisher yield, but the effect was weak in both cases. No habitat variable (forest cover or

378 agricultural cover) explained changes in marten yield in the hardwood forest and

379 coniferous forest zones. In the mixed forest zone, marten yields decreased with increasing

380 cover of agricultural fields (Fig. 5). Marten yield decreased with the number of days with

381 rain and the amount of rainfall in the winter preceding the trapping season in the mixed

382 forest zone (Fig. 6). In the coniferous forest zone, marten yield increased with the amount

383 of rainfall during the trapping season (Fig. 7).

384 DISCUSSION

385 Habitat Changes

386 Fisher.-Fisher yield increased in all 3 zones, but more strongly in the hardwood

387 forest and mixed forest zones. Although still low, fisher yield increased in the coniferous

388 forest zone, where the species is at the northern edge of its range and densities are

389 inherently low. The abundance of mixedwood stands $>12 \mathrm{~m}$ increased fisher yields in

390 both hardwood and coniferous forest zones. Deciduous stands $>12 \mathrm{~m}$ were not a good

391 indicator of fisher populations at the landscape scale. According to other studies, the

392 coniferous component of stands appears to be particularly important for fishers in Quebec

393 (Proulx 2006, Sauder and Rachlow 2014, Fuller et al. 2016). Kelly (1977) determined 
18 | Suffice et al.

394 that fishers avoid forest stands that are composed of $\geq 74 \%$ deciduous trees. Deciduous-

395 dominated stands probably do not provide fishers with optimal conditions for winter

396 movement. Because of their crown form, boreal softwood species provide cover that

397 protects fishers by intercepting precipitation, including snow. In winter, fishers

398 preferentially use dense stands with a large conifer component (mixed or dominant),

399 given lower accumulations of snow on the ground, thereby facilitating movements (Raine

400 1983, Hopkinson et al. 2004). Within a forest matrix dominated by deciduous tree

401 species, the coniferous component becomes particularly attractive for fisher movement.

402 In the mixed forest zone, no habitat variable could explain increases in fisher yields, yet

403 the habitat appears to remain adequate for the needs of fisher populations.

404 In the coniferous forest zone, the increase in fisher yield was associated with

405 mixedwood stands $>12 \mathrm{~m}$, which have increased in proportion over the past 30 years. On

406 the one hand, a mixed species composition provides the best compromise for fisher in

407 terms of structures that can intercept snow while providing a variety of prey (Powell et al.

408 2003). On the other hand, in the coniferous forest zone, the amount of deciduous stands

$409>12 \mathrm{~m}$ reduces fisher yields. These forest stands have little or no structure to intercept

410 snow. Logging intensity in the coniferous forest zone favored early successional species,

411 such as trembling aspen (Populus tremuloides), at the expense of conifers that dominated

412 the canopy in pre-industrial times (Boucher et al. 2014, Grondin et al. 2018).

413 Modifications of the cover type and their associations with fisher captures support

414 the hypotheses based on trapper knowledge (Table 1). Indeed, trappers have reported that

415 fishers in Quebec use forests where the deciduous component has increased (Suffice et al.

416 2017). Fishers especially use forests with complex structures, both vertically (several 
19 | Suffice et al.

417 layers of vegetation) and horizontally (downed woody debris; Powell and Zielinski

418 1994). The deciduous component provides fishers with a diversity of structure and an

419 abundance of prey species (Poulin et al. 2006). Studies in eastern Maine and Connecticut,

420 USA, reported that fishers live in mixedwood and deciduous stands (Arthur et al. 1989,

421 Kilpatrick and Rego 1994). Trappers in our study area shared their concerns about the

422 availability of large hollow trees in which the fisher could find refuge and raise their

423 young (Suffice et al. 2017). Indeed, fishers typically use resting sites in large living trees

424 with cavities or broken tops, or in large dead trees (Gess et al. 2013, Green 2017). The

425 size of the trees that can be used as resting sites varies according to bioclimatic zone and

426 tree species available (Weir and Almuedo 2010, Aubry et al. 2013). In the eastern portion

427 of its range, fishers mainly use deciduous trees with an average diameter at breast height

$428>50 \mathrm{~cm}$ (Erb et al. 2013, Gess et al. 2013). In northern Quebec, trees $>30 \mathrm{~cm}$ in diameter

429 are rare (Vaillancourt et al. 2008), yet fisher populations have increased in the coniferous

430 forest zone (spruce-moss bioclimatic domain). As in other regions, fishers in Quebec may

431 use ground-level dens more than large-diameter trees (Kilpatrick and Rego 1994, Gess et

432 al. 2013, Green 2017).

433 In interviews conducted by Suffice et al. (2017), trappers noted that they were

434 capturing greater numbers of fishers at farmland edges and that the animals could use

435 relatively open landscapes. Our analyses could not confirm these observations by trappers

436 made at a finer spatial scale. The quantity of agricultural fields in Quebec varied little

437 between 1984 and 2015. Furthermore, the amount of land under agriculture likely does

438 not reflect the quantity of edge between agricultural fields and forest stands used by

439 fishers (Bridger et al. 2017). 
20 | Suffice et al.

Marten.-No habitat variable explained the decrease in marten yields in the

441 hardwood forest and mixed forest zones, where stands have increased both in area and

442 height. We found no change in marten yield over time in the coniferous forest zone. In

443 addition, changes in forest cover across Quebec did not influence marten populations, yet

444 martens have been reported to occupy mature forest stands with dense cover and complex

445 structure (Buskirk and Ruggiero 1994, Bissonette et al. 1997, Chapin et al. 1998, Potvin

446 et al. 2000, Fuller et al. 2005). Indeed, Cheveau et al. (2013) reported that in a

447 predominantly coniferous (spruce) landscape, mixedwood stands were selected at home

448 range and landscape scales. Trappers mentioned that they often capture marten in

449 deciduous stands (Suffice et al. 2017). In conifer-dominated landscapes, martens seek out

450 a diversity of habitat attributes to find food and protection. The quantity of coniferous

451 stands, however, does not explain marten yields in Quebec, maybe because simply

452 defining stands according to their height class does not reflect their structural complexity

453 (McCann et al. 2014). Further, by analyzing interactions at such a broad spatial scale,

454 habitat loss observed by trappers at the trapline scale and its effect on local marten

455 populations were likely underestimated.

\section{Changes in Rain Conditions}

457 The variables describing rain conditions contributed to the most supported models in all 3

458 zones, but only the amount of cold rain during the previous spring influenced fisher yield

459 in the mixed and coniferous forest zones. Although fisher yield decreased with increasing

460 amount of cold rain during the previous spring, fisher yield increased in both zones. As

461 expected, in the mixed forest zone, marten yields decreased with increasing amounts of

462 rainfall and number of days with rainfall in the winter preceding the trapping season. The 
21 | Suffice et al.

463 amount of rainfall during the trapping season increased marten yields only in the

464 coniferous forest zone. Rain increases snow density and promotes ice crust formation on

465 the snow surface that could limit access to subnivean areas used for cover and to access

466 food (Callaghan and Johansson 2015, Williams et al. 2015, Domine et al. 2018). Cold

467 rain could also exert direct effects on marten thermoregulation (Taylor and Buskirk

468 1994). Martens have few fat reserves, which makes them potentially vulnerable to the

469 cold when their fur is wet (Buskirk and Harlow 1989). Increased rainfall could incur

470 greater natural winter mortality in adult martens. By limiting marten access to subnivean

471 space, rain-induced snow-crusting can cause marten to move more in search of food

472 resources. Increasing rainfall during the trapping season facilitates traveling by snowshoe

473 or snowmobile, and potentially increases the efficiency of trappers. Moreover, rain can

474 increase marten vulnerability to trapping. High marten yields during a rainy trapping

475 season can lead to a lower harvest in the following year. Phenomena that are observed at

476 the local scale by Quebec trappers are difficult to capture at the provincial scale. In

477 addition, our study used data over 30 years, which represents a relatively short time scale

478 compared to longer-term climate change. The use of average weather conditions over

479 large areas (FAMUs) and annual time steps was also unlikely to portray spatial and

480 temporal variation that would better represent freeze-thaw events affecting animal

481 survival.

482 Weather conditions favoring increased snow load-bearing capacity could also

483 have indirect effects on marten and fisher populations by influencing interspecific

484 competition. Karniski (2014) observed responses along these lines in the Adirondack

485 Mountains, northeastern United States. More compact snow favors movement of coyote 
22 | Suffice et al.

486 and red fox, which are 2 potential competitors or predators of martens and fishers

487 (Pozzanghera et al. 2016, Suffice et al. 2017). Thus, snow compaction could have an

488 indirect negative effect on marten and fisher by increasing competition with other

489 mesocarnivores, which would also mitigate the positive effect of snow compaction on

490 fisher movement.

491 Cumulative Effects and Relative Importance of Habitat and Climate Change

492 In this study, changes in forest cover exerted stronger effects on fisher than did rainfall

493 conditions. Too much emphasis is sometimes placed on climate change in biodiversity

494 scenarios, when other variables that arise from human activities may have similar or even

495 greater effects at shorter time scales (Titeux et al. 2016). Modifications of wildlife

496 habitats through land use conversion and exploitation of natural resources are considered

497 to be among the most important and immediate threats to biodiversity (Newbold et al.

498 2015). Climate change and human activities exert cumulative effects on plant and animal

499 species compositions, the changes of which can affect the distribution of fisher and

500 marten (Carroll 2007, Lawler et al. 2012, Lavoie et al. 2019). The greatest change in the

501 forest landscapes of North America is the migration or even reduction of conifer-

502 dominated stands, which are replaced by mixedwood or deciduous stands (Lawler et al.

503 2012, Purcell et al. 2012, Zielinski et al. 2012). An increased risk of windthrow is also

504 expected to occur in eastern Canada, mainly through an increased period during which

505 the ground is unfrozen (Saad et al. 2017). These changes could favor the creation of

506 micro-habitats for small mammals and create new structures that could be exploited in

507 the subnivean environment. 
23 | Suffice et al.

In addition to logging, climate change that affects forest fire regimes is expected

509 to result in the loss of late-successional vegetation, which may increase the probability of

510 extirpation of associated species, such as fisher and marten (Bergeron et al. 2010, Lawler

511 et al. 2012, Purcell et al. 2012). Changes in winter conditions should facilitate the

512 movement of fishers and other mesocarnivores, and may change the partitioning of

513 niches based upon snow characteristics (Whiteman and Buskirk 2013, Manlick et al.

514 2017). Indeed, many medium-sized predators have already expanded their ranges, which

515 can affect food webs and trophic controls (Prugh et al. 2009, Pokallus and Pauli 2015).

516 Species conservation and habitat management in response to climate change pose the

517 challenge of balancing the need to maintain current habitat and anticipate future changes

518 in habitat and species distributions. Climate change scenarios predict conditions that

519 favor fishers, but data that have been obtained by Zielinski et al. (2017) suggest that

520 martens may be able to shift their niche to include warmer, less snowy areas.

521 Conservation of interacting species at the boundaries of their ranges requires managers to

522 be aware of interspecies tolerance, how each would uniquely respond to future climates,

523 and how potential climate refuges could be integrated into existing habitat (Morelli et al.

524 2016, Zielinski et al. 2017).

\section{Inter-Specific Relations: The Missing Link?}

526 Abundance of prey, competitors, and predators have been identified by trappers as major

527 factors that may explain changes in fisher and marten abundance (Suffice et al. 2017).

528 Behavioral changes caused by interspecific competition and by intraguild predation or

529 interspecific killing can have repercussions on the distribution of individuals, even

530 species (King and Moors 1979, Tannerfeldt et al. 2002, Eriksson et al. 2019). 
24 | Suffice et al.

531 Unfortunately, prey, competitor, and predator abundance variables were unavailable at

532 the scale of our study. Variation in marten catches could be more closely related to

533 fluctuations in food supply (Cheveau et al. 2004, Jensen et al. 2012, Fauteux et al. 2015)

534 than to habitat quality or climatic variation, although this remains to be demonstrated.

535 Environmental changes in recent decades have contributed to changes in the distribution

536 of fishers but also of other marten competitors. An assessment of the co-occurrence of

537 mesocarnivores, as was conducted by Gompper et al. (2016), would make it possible to

538 better consider the role of biotic factors in population dynamics.

539 Manlick et al. (2017) suggested that landscape homogenization leads to niche

540 compression and that marten populations would be limited through increased competition

541 with fishers. Dietary overlap between marten and fisher likely intensifies interspecific

542 competition through interference, as previously demonstrated in Wisconsin, USA

543 (Manlick et al. 2017). Dietary overlap is also a major predictor of intraguild predation

544 (Donadio and Buskirk 2006), as observed by McCann et al. (2010) in Wisconsin, where

545 fishers were the most common cause of winter mortality in marten. An inverse

546 relationship between marten and fisher occurrence has already been observed in several

547 sympatric populations, where coexistence has been attributed to mechanisms that reduce

548 competition for shared resources, such as spatiotemporal segregation, differential habitat

549 selection, and contrasting use of snow cover (Krohn et al. 1997, Fisher et al. 2013). In our

550 analyses, marten yields declined in the hardwood and mixed forest zones, where fisher

551 yields had increased the most. In the coniferous forest zone, where increases in fisher

552 yield were low, marten yield has yet to decrease. These results suggest that habitat use by

553 fisher and marten in Quebec may be influenced especially by interspecific relationships, 
554 but this remains speculative. Thus, the co-occurrence characteristics of the 2 species need

555 to be studied at a finer spatial scale.

\section{MANAGEMENT IMPLICATIONS}

557 Pelt sales data can contribute to documentation of trends in furbearing populations over 558 the long-term and over large spatial scales (e.g., provincial or state forest zones). Closer 559 partnerships between government and wildlife users could also improve the efficiency of 560 population monitoring for species that are difficult to sample. In our case, involving 561 trappers in such a process contributed to the construction of testable hypotheses on 562 species ecology that can inform species management. To improve the quality of the 563 information provided by trappers in future research, we suggest they should be invited by 564 wildlife state and provincial agencies to share information on trapping effort and capture 565 location. In addition, trappers could supply carcasses to researchers to help monitor long566 term fisher and marten physical condition and reproductive success according to 567 changing winter climate conditions.

568 The negative effect of winter rain on fisher and marten populations highlights the 569 need for protective cover to cope with climate change, particularly in an industrial forest 570 landscape. Although coniferous trees intercept rainfall and snowfall, old hardwood trees

571 can provide natural cavities for thermoregulation. Thus, managers should strive to 572 promote and maintain mixedwood stands taller than $12 \mathrm{~m}$ to maintain protective cover 573 and high-quality habitat for fishers.

\section{ACKNOWLEDGMENTS}

575 We thank M. Desrochers for geomatics analyses, J. Alluard for statistical analysis, R. St576 Amant for his advice regarding the use of BioSIM, and W. F. J. Parsons for English 
26 | Suffice et al.

577 translation. We are indebted to the trappers for having formulated hypotheses based on

578 their experience and knowledge. Lastly, we thank P. Fournier for sharing his expertise on

579 trapping and field work. This project was supported by a grant from the Fonds de

580 Recherche du Québec - Nature et Technologies.

581 LITERATURE CITED

582 Angers, V. A., C. Messier, M. Beaudet, and A. Leduc. 2005. Comparing composition and 583 structure in old-growth and harvested (selection and diameter-limit cuts) northern

Arthur, S. M., W. B. Krohn, and J. R. Gilbert. 1989. Home range characteristics of adult hardwood stands in Quebec. Forest Ecology and Management 217:275-293.

Aubry, K. B., C. M. Raley, S. W. Buskirk, W. J. Zielinski, M. K. Schwartz, R. T. habitat selection by fishers at resting sites in the Pacific coastal region. Journal of

Aylward, C. M., J. D. Murdoch, T. M. Donovan, C. W. Kilpatrick, C. Bernier, and J. Katz. 2018. Estimating distribution and connectivity of recolonizing American marten in the northeastern United States using expert elicitation techniques. Animal Conservation 21:483-495.

595 Bergeron, Y., D. Cyr, C. R. Drever, M. Flannigan, S. Gauthier, D. Kneeshaw, È. Lauzon, 596 A. Leduc, H. L. Goff, D. Lesieur, and K. Logan. 2006. Past, current, and future fire 597 frequencies in Quebec's commercial forests: implications for the cumulative effects 598 of harvesting and fire on age-class structure and natural disturbance-based 599 management. Canadian Journal of Forest Research 36:2737-2744. 
27 | Suffice et al.

600

601

602

603

604

605

606

607

608

609

610

611

612

613

614

615

616

617

618

619

620

621

Bergeron, Y., D. Cyr, M. P. Girardin, and C. Carcaillet. 2010. Will climate change drive 21st century burn rates in Canadian boreal forest outside of its natural variability: collating global climate model experiments with sedimentary charcoal data. International Journal of Wildland Fire 19:1127-1139.

Berteaux, D., G. Gauthier, F. Domine, R. A. Ims, S. F. Lamoureux, E. Lévesque, and N. Yoccoz. 2017. Effects of changing permafrost and snow conditions on tundra wildlife: critical places and times. Arctic Science 3:65-90.

Bertrand, P., J. Bowman, R. J. Dyer, M. Manseau, and P. J. Wilson. 2017. Sex-specific graphs: relating group-specific topology to demographic and landscape data. Molecular Ecology 26:3898-3912.

Bissonette, J. A., D. J. Harrison, C. D. Hargis, and T. G. Chapin. 1997. The influence of spatial scale and scale-sensitive properties on habitat selection by American marten. Pages 368-385 in J. A. Bissonette, editor. Wildlife and landscape ecology: effects of pattern and scale. Springer, New York, New York, USA.

Boucher, D., S. Gauthier, J. Noël, D. F. Greene, and Y. Bergeron. 2014. Salvage logging affects early post-fire tree composition in Canadian boreal forest. Forest Ecology and Management 325:118-127.

Bowman, J. C., D. Donovan, and R. C. Rosatte. 2006. Numerical response of fishers to synchronous prey dynamics. Journal of Mammalogy 87:480-484.

Bridger, M. C., C. J. Johnson, and M. P. Gillingham. 2017. Working with experts to quantify changes in the abundance of furbearers following rapid and large-scale forest harvesting. Forest Ecology and Management 402:194-203. 
28 | Suffice et al.

622 Burnham, K. P., and D. R. Anderson. 2002. Model selection and multimodel inference: a 623 practical information-theoretic approach. Second edition. Springer, New York, New $624 \quad$ York, USA.

625 Buskirk, S. W. 1992. Conserving circumpolar forests for martens and fishers.

626 Conservation Biology 6:318-320.

627 Buskirk, S. W., and H. J. Harlow. 1989. Body-fat dynamics of the American marten 628 (Martes americana) in winter. Journal of Mammalogy 70:191-193.

629 Buskirk, S. W., and L. F. Ruggiero. 1994. American marten. Pages 38-73 in L. F. 630 Ruggiero, K. B. Aubry, S. W. Buskirk, L. J. Lyon, and W. J. Zielinski, technical 631 editors. The scientific basis for conserving forest carnivores: American marten, 632 fisher, lynx, and wolverine in the western United States. General Technical Report 633 RM-254. USDA, Forest Service, Rocky Mountain Research Station, Fort Collins, 634 Colorado, USA.

635 Callaghan, T. V., and M. Johansson. 2015. Snow, ice, and the biosphere. Pages 139-165

636 in J. F. Shroder, W. Haeberli, and C. Whiteman, editors. Snow and ice-related 637 hazards, risks and disasters. Academic Press, Boston, Massachusetts, USA.

638 Carr, D., J. Bowman, C. J. Kyle, S. M. Tully, E. L. Koen, J.-F. Robitaille, and P. J. 639 Wilson. 2007a. Rapid homogenization of multiple sources: genetic structure of a 640 recolonizing population of fishers. Journal of Wildlife Management 71:1853-1861.

641 Carr, D., J. Bowman, and P. J. Wilson. 2007b. Density-dependent dispersal suggests a 642 genetic measure of habitat suitability. Oikos 116:629-635. 
29 | Suffice et al.

643 Carroll, C. 2007. Interacting effects of climate change, landscape conversion, and harvest 644 on carnivore populations at the range margin: marten and lynx in the Northern 645 Appalachians. Conservation Biology 21:1092-1104.

646 Chapin, T. G., D. J. Harrison, and D. D. Katnik. 1998. Influence of landscape pattern on 647 habitat use by American marten in an industrial forest. Conservation Biology $648 \quad 12: 1327-1337$.

649 Cheveau, M., P. Drapeau, L. Imbeau, and Y. Bergeron. 2004. Owl winter irruptions as an 650 indicator of small mammal population cycles in the boreal forest of eastern North $651 \quad$ America. Oikos 107:190-198.

652 Cheveau, M., L. Imbeau, D. Drapeau, and L. Bélanger. 2013. Marten space use and 653 habitat selection in managed coniferous boreal forests of eastern Canada. Journal of 654 Wildlife Management 77:749-760.

655 Crête, M., and S. Larivière. 2003. Estimating the costs of locomotion in snow for 656 coyotes. Canadian Journal of Zoology 81:1808-1814.

657 Domine, F., G. Gauthier, V. Vionnet, D. Fauteux, M. Dumont, and M. Barrere. 2018.

658 Snow physical properties may be a significant determinant of lemming population 659 dynamics in the high Arctic. Arctic Science 4:813-826.

660 Domon, G., G. Beaudet, and M. Joly. 2000. Évolution du territoire laurentidien: 661 caractérisation et gestion des paysages. Isabelle Quintin éditeur, Montréal, Québec, 662 Canada.

663 Domon, G., and A. Bouchard. 2007. The landscape history of Godmanchester (Quebec, 664 Canada): two centuries of shifting relationships between anthropic and biophysical 665 factors. Landscape Ecology 22:1201-1214. 
30 | Suffice et al.

666 Donadio, E., and S. W. Buskirk. 2006. Diet, morphology, and interspecific killing in 667 carnivora. American Naturalist 167:524-536.

668 Drapeau, P., A. Leduc, J.-F. Giroux, J. L. Savard, Y. Bergeron, and W. L. Vickery. 2000.

669 Landscape-scale disturbances and changes in bird communities of the boreal mix670 wood forests. Ecological Monographs 70:423-444.

671 Erb, J., P. Coy, and B. Sampson. 2013. Reproductive ecology of fishers and American 672 martens in Minnesota. Pages 100-109 in L. Cornicelli, M. Carstensen, M. D. Grund, 673 M. A. Larson, and J. S. Lawrence, editors. Summaries of wildlife research findings. 674 Minnesota Department of Natural Resources, St. Paul, USA.

675 Eriksson, C. E., K. M. Moriarty, M. A. Linnell, and T. Levi. 2019. Biotic factors

676 influencing the unexpected distribution of a Humboldt marten (Martes caurina 677 humboldtensis) population in a young coastal forest. PLoS ONE 14(5):e0214653.

678 Fauteux, D., M. Cheveau, L. Imbeau, and P. Drapeau. 2015. Cyclic dynamics of a boreal 679 southern red-backed vole population in northwestern Quebec. Journal of $680 \quad$ Mammalogy 96:573-578.

681 Fisher, J. T., B. Anholt, S. Bradbury, M. Wheatley, and J. P. Volpe. 2013. Spatial 682 segregation of sympatric marten and fishers: the influence of landscapes and species683 scapes. Ecography 36:240-248.

684 Fuller, A. K., and D. J. Harrison. 2005. Influence of partial timber harvesting on 685 American martens in north-central Maine. Journal of Wildlife Management 69:710686 722. 
31 | Suffice et al.

687 Fuller, A. K., and D. J. Harrison. 2013. Modeling the influence of forest structure on

688 microsite habitat use by snowshoe hares. International Journal of Forestry Research:

$689 \quad 1-7$.

690 Fuller, A. K., D. W. Linden, and J. A. Royle. 2016. Management decision making for 691 fisher populations informed by occupancy modeling. Journal of Wildlife 692 Management 80:794-802.

693 Garroway, C. J., J. Bowman, and P. J. Wilson. 2011. Using a genetic network to 694 parameterize a landscape resistance surface for fishers, Martes pennanti. Molecular $695 \quad$ Ecology 20:3978-3988.

696 Gese, E. M. 2001. Monitoring of terrestrial carnivore populations. Pages 372-396 in J. L.

697 Gittleman, S. M. Funk, D. W. Macdonald, and R. K. Wayne, editors. Carnivore 698 conservation. Cambridge University Press, Cambridge, United Kingdom.

699 Gess, S. W., E. H. Ellington, M. R. Dzialak, J. E. Duchamp, M. Lovallo, and J. L. Larkin. 700 2013. Rest-site selection by fishers (Martes pennanti) in the eastern deciduous forest. $701 \quad$ Wildlife Society Bulletin 37:805-814.

702 Gompper, M. E., D. B. Lesmeister, J. C. Ray, J. R. Malcolm, and R. Kays. 2016.

703 Differential habitat use or intraguild interactions: what structures a carnivore $704 \quad$ community? PLoS ONE 11(1):e0146055.

705 Gouvernement du Québec. 2019. Normales climatiques 1981-2010; Climat du Québec. $706<$ http://www.environnement.gouv.qc.ca/climat/normales/climat-qc.htm>. Accessed 5 $707 \quad$ Mar 2019.

708 Gouvernement du Québec, and Fédération des trappeurs gestionnaires du Québec. 2019. 709 Trapping and management of furbearing animals: safety and wildlife conservation 
32 | Suffice et al.

educational program. Programme d'éducation en sécurité et en conservation de la faune (PESCOF). Fédération des trappeurs Gestionnaires du Québec, Québec, Québec, Canada.

Graham, R. W., and E. C. Grimm. 1990. Effects of global climate change on the patterns of terrestrial biological communities. Trends in Ecology and Evolution 5:289-292.

Green, R. E. 2017. Reproductive ecology of the fisher (Pekania pennanti) in the Southern Sierra Nevada: an assessment of reproductive parameters and forest habitat used by denning females. Dissertation, University of California, Davis, USA.

Grondin, P., S. Gauthier, V. Poirier, P. Tardif, Y. Boucher, and Y. Bergeron. 2018. Have some landscapes in the eastern Canadian boreal forest moved beyond their natural range of variability? Forest Ecosystems 5(1):1-17.

Hopkinson, C., M. Sitar, L. Chasmer, and P. Treitz. 2004. Mapping snowpack depth beneath forest canopies using airborne lidar. Photogrammetric Engineering \& Remote Sensing 70:323-330.

Jensen, P. G., C. L. Demers, S. A. McNulty, W. J. Jakubas, and M. M. Humphries. 2012. Marten and fisher responses to fluctuations in prey populations and mast crops in the northern hardwood forest. Journal of Wildlife Management 76:489-502.

Jobin, B., J. Beaulieu, M. Grenier, L. Bélanger, C. Maisonneuve, D. Bordage, and B. Filion. 2003. Landscape changes and ecological studies in agricultural regions, Québec, Canada. Landscape Ecology 18:575-590.

Karniski, N. 2014. The effects of snow on American martens (Martes americana) and fishers (Martes pennanti) in the Adirondack Mountains of New York. Dissertation, State University of New York, Syracuse, USA. 
33 | Suffice et al.

733 Kawaguchi, T., A. Desrochers, and H. Bastien. 2015. Snow tracking and trapping harvest 734 as reliable sources for inferring abundance: a 9-year comparison. Northeastern $735 \quad$ Naturalist 22:798-811.

736 Kelly, G. M. 1977. Fisher (Martes pennanti) biology in the White Mountain National 737 Forest and adjacent areas. Dissertation, University of Massachusetts, Amherst, USA.

738 Kilpatrick, H. J., and P. W. Rego. 1994. Influence of season, sex, and site availability on 739 fisher (Martes pennanti) rest-site selection in the central hardwood forest. Canadian $740 \quad$ Journal of Zoology 72:1416-1419.

741 King, C. M., and P. J. Moors. 1979. On co-existence, foraging strategy and the 742 biogeography of weasels and stoats (Mustela nivalis and M. erminea) in Britain. $743 \quad$ Oecologia 39:129-150.

744 Krohn, W. B. 2012. Distribution changes of American martens and fishers in eastern 745 North America, 1699-2001. Pages 58-73 in K. B. Aubry, W. J. Zielinski, M. G. 746 Raphael, G. Proulx, and S. W. Buskirk, editors. Biology and conservation of

Krohn, W., C. Hoving, D. Harrison, D. Phillips, and H. Frost. 2005. Martes foot-loading

750 and snowfall patterns in eastern North America: implications to broad-scale 751 distributions and interactions of mesocarnivores. Pages 115-131 in D. J. Harrison, A.

752 K. Fuller, and G. Proulx, editors. Martens and fishers (Martes) in human-altered 753 environments. Springer, Boston, Massachusetts, USA.

754 Krohn, W. B., W. J. Zielinski, and R. B. Boone. 1997. Relations among fishers, snow, 755 and martens in California: results from small-scale spatial comparisons. Pages 211- 
34 | Suffice et al.

232 in G. Proulx, H. N. Bryant, and P. M. Woodard, editors. Martes: taxonomy, ecology, techniques and management. Second International Martes Symposium, 1216 August 1995, Provincial Museum of Alberta, Edmonton, Alberta, Canada.

Lancaster, P. A., J. Bowman, and B. A. Pond. 2008. Fishers, farms, and forests in eastern North America. Environmental Management 42:93-101.

LaPoint, S. D., J. L. Belant, and R. W. Kays. 2015. Mesopredator release facilitates range expansion in fisher. Animal Conservation 18:50-61.

Lavoie, M., A. Renard, and S. Larivière. 2019. Timber harvest jeopardize marten persistence in the heart of its range. Forest Ecology and Management 442:46-52.

Lawler, J. J., H. D. Safford, and E. H. Girvetz. 2012. Martens and fishers in a changing climate. Pages 371-397 in K. B. Aubry, W. J. Zielinski, M. G. Raphael, G. Proulx, and S. W. Buskirk, editors. Biology and conservation of martens, sables, and fishers: a new synthesis. Cornell University Press, Ithaca, New York, USA.

Lemieux, L., P. Leboeuf, and J. P. Berger. 2015. Norme de photo-interprétation: quatrième inventaire écoforestier du Québec méridional. Gouvernement du Québec, Ministère des Forêts, de la Faune et des Parcs, Direction des inventaires forestiers, Secteur des Forêts, Québec, Québec, Canada.

Létourneau, J.-P., A. Bard, and J. Lambert. 2009. Normes de cartographie écoforestière: troisième inventaire écoforestier. Gouvernement du Québec, Ministère des Ressources naturelles et de la Faune, Direction des inventaires forestiers, Québec, Québec, Canada. 
35 | Suffice et al.

777 Lewis, J. C., R. A. Powell, and W. J. Zielinski. 2012. Carnivore translocations and 778 conservation: insights from population models and field data for fishers (Martes 779 pennanti). PLoS ONE 7(3):e32726.

780 Lodge, D. M. 1993. Species invasions and deletions: community effects and responses to 781 climate and habitat change. Pages 376-387 in P. M. Kareiva, J. G. Kingsolver, and 782 R. B. Huey, editors. Biotic interactions and global change. Sinauer Associates, 783 Sunderland, Massachusetts, USA.

784 Macdonald, D. W., and C. Newman. 2002. Population dynamics of badgers (Meles 785 meles) in Oxfordshire, U.K.: numbers, density and cohort life histories, and a 786 787 and fishers (Pekania pennanti). Journal of Mammalogy 98:690-702.

Mazerolle, M. J. 2017. AICcmodavg: model selection and multimodel inference based on (Q)AIC(c). R package version 2.1-1. <https://cran.r-

793 project.org/package=AICcmodavg>. Accessed 21 Jul 2019.

794 McCann, N. P., P. A. Zollner, and J. H. Gilbert. 2010. Survival of adult martens in 795 northern Wisconsin. Journal of Wildlife Management 74:1502-1507.

796 McCann, N. P., P. A. Zollner, and J. H. Gilbert. 2014. Bias in the use of broadscale 797 vegetation data in the analysis of habitat selection. Journal of Mammalogy 95:369381. 
36 | Suffice et al.

799 Ministère de l'énergie et des ressources du Québec. 1984. Normes d'inventaire forestier.

800 Gouvernement du Québec, Ministère de l'énergie et des ressources du Québec,

801 Direction générale des publications gouvernementales, Québec, Québec, Canada.

802 Morelli, T. L., C. Daly, S. Z. Dobrowski, D. M. Dulen, J. L. Ebersole, S. T. Jackson, J. D.

803 Lundquist, C. I. Millar, S. P. Maher, W. B. Monahan, et al. 2016. Managing climate

804 change refugia for climate adaptation. PLoS ONE 11(8):e0159909.

805 Newbold, T., L. N. Hudson, S. L. L. Hill, S. Contu, I. Lysenko, R. A. Senior, L. Borger,

806 D. J. Bennett, A. Choimes, B. Collen, et al. 2015. Global effects of land use on local

807 terrestrial biodiversity. Nature 520:45-50.

808 Payer, D., and D. Harrison. 2005. Relationships between forest structure and habitat use

809 by American martens in Maine, USA. Pages 173-186 in D. J. Harrison, A. K. Fuller,

810 and G. Proulx, editors. Martens and fishers (Martes) in human-altered environments.

811 Springer, Boston, Massachusetts, USA.

812 Pelletier, G., Y. Dumont, and M. Bédard. 2007. SIFORT: système d'Information

813 FORestière par Tesselle. Manuel de l'usager. Gouvernement du Québec, Ministère

814 des Ressources Naturelles et de la Faune du Québec, Québec, Québec, Canada.

815 Pinheiro, J. C., and D. M. Bates. 2000. Mixed-effects models in S and S-PLUS. Springer

816 Verlag, New York, New York, USA.

817 Pinheiro, J. C., D. M. Bates, S. DebRoy, D. R. Sarkar, and R Core team. 2018. nlme:

818 linear and nonlinear mixed effects models. R package version 3.1-137.

$819<$ https://CRAN. R-project. org/package=nlme>. Accessed 27 Apr 2018. 
37 | Suffice et al.

820 Plante, S., C. Dussault, J. H. Richard, and S. D. Coté. 2018. Human disturbance effects

821 and cumulative habitat loss in endangered migratory caribou. Biological

$822 \quad$ Conservation 224:129-143.

823 Pokallus, J. W., and J. N. Pauli. 2015. Population dynamics of a northern-adapted

824 mammal: disentangling the influence of predation and climate change. Ecological

$825 \quad$ Applications 25:1546-1556.

826 Potvin, F., L. Bélanger, and K. Lowell. 2000. Marten habitat selection in a clearcut boreal

827 landscape. Conservation Biology 14:844-857.

828 Potvin, F., L. Breton, and R. Courtois. 2005. Response of beaver, moose, and snowshoe

829 hare to clear-cutting in a Quebec boreal forest: a reassessment 10 years after cut.

830 Canadian Journal of Forest Research 35(1):151-160.

831 Poulin, J.-F., H. Jolicoeur, P. Canac-Marquis, and S. Larivière. 2006. Investigation sur les

832 facteurs à l'origine de la hausse de la récolte de pékans (Martes pennanti) au Québec

833 depuis 1984. Gouvernement du Québec, Ministère des Ressources naturelles et de la

834 Faune du Québec, Direction du développement de la faune, and Université du

835 Québec à Rimouski, Département de biologie et des sciences de la santé, Québec,

836 Québec, Canada.

837 Powell, R. A., S. W. Buskirk, and W. J. Zielinski. 2003. Fisher and marten (Martes

838 pennanti and Martes americana). Pages 635-649 in G. A. Feldhamer, B. C.

839 Thompson, and J. A. Chapman, editors. Wild mammals of North America. Johns

840 Hopkins University Press, Baltimore, Maryland, USA.

841 Powell, R. A., and W. J. Zielinski. 1994. Fisher. Pages 38-73 in L. F. Ruggiero, K. B.

842 Aubry, S. W. Buskirk, L. J. Lyon, and W. J. Zielinski, editors. The scientific basis 
38 | Suffice et al.

for conservation of forest carnivores: American marten, fisher, lynx and wolverine in the western United States. General Technical Report RM-GTR-254. USDA, Forest Service, Rocky Mountain Forest and Range Experiment Station, Fort Collins, Colorado, USA.

Pozzanghera, C. B., K. J. Sivy, M. S. Lindberg, and L. R. Prugh. 2016. Variable effects of snow conditions across boreal mesocarnivore species. Canadian Journal of Zoology 94:697-705.

Proulx, G. 2006. Using forest inventory data to predict winter habitat use by fisher Martes pennanti in British Columbia, Canada. Acta Theriologica 51:275-282.

Prugh, L. R., C. J. Stoner, C. W. Epps, W. T. Bean, W. J. Ripple, A. S. Laliberte, and J. S. Brashares. 2009. The rise of the mesopredator. BioScience 59:779-791.

Purcell, K. L., C. M. Thompson, and W. J. Zielinski. 2012. Fishers and American martens. Pages 47-60 in M. North, editor. Managing Sierra Nevada forests. General Technical Report PSW-GTR-237. USDA, Forest Service, Pacific Southwest Research Station, Albany, California, USA.

Raine, R. M. 1983. Winter habitat use and responses to snow cover of fisher (Martes pennanti) and marten (Martes americana) in southeastern Manitoba. Canadian Journal of Zoology 61:25-34.

Raine, R. M. 1987. Winter food habits and foraging behaviour of fishers (Martes pennanti) and martens (Martes americana) in southeastern Manitoba. Canadian Journal of Zoology 65:745-747. 
39 | Suffice et al.

864 Régnière, J., and R. St-Amant. 2007. Stochastic simulation of daily air temperature and 865 precipitation from monthly normals in North America north of Mexico. International 866 Journal of Biometeorology 51:415-430.

867 Régnière, J., R. St-Amant, A. Béchard, and A. Moutaoufik. 2017. BioSIM 11 user’s 868

Reif, J. 2013. Long-term trends in bird populations: a review of patterns and potential

872 Saad, C., Y. Boulanger, M. Beaudet, P. Gachon, J.-C. Ruel, and S. Gauthier. 2017. Potential impact of climate change on the risk of windthrow in eastern Canada's forests. Climatic Change 143:487-501.

Sauder, J. D., and J. L. Rachlow. 2014. Both forest composition and configuration influence landscape-scale habitat selection by fishers (Pekania pennanti) in mixed coniferous forests of the Northern Rocky Mountains. Forest Ecology and Management 314:75-84.

Schulte, L. A., D. J. Mladenoff, T. R. Crow, L. C. Merrick, and D. T. Cleland. 2007. Homogenization of northern U.S. Great Lakes forests due to land use. Landscape Ecology 22:1089-1103.

Sherburne, S. S., and J. A. Bissonette. 1994. Marten subnivean access point use: response to subnivean prey levels. Journal of Wildlife Management 58:400-405.

Spencer, W. D., H. Rustigian-Romsos, K. Ferschweiler, and D. Bachelet 2015. Simulating effects of climate and vegetation change on distributions of martens and fishers in the Sierra Nevada, California, using Maxent and MC1. Pages 135-149 in 
40 | Suffice et al.

D. Bachelet and D. Turner, editors. Global vegetation dynamics: concepts and applications in the MC1 Model. Geophysical Monograph Series 213. First edition. Wiley, Hoboken, New Jersey, USA.

Stewart, F. E. C., J. P. Volpe, J. S. Taylor, J. Bowman, P. J. Thomas, M. J. Pybus, and J. T. Fisher. 2017. Distinguishing reintroduction from recolonization with genetic testing. Biological Conservation 214:242-249.

Suffice, P., H. Asselin, L. Imbeau, M. Cheveau, and P. Drapeau. 2017. More fishers and fewer martens due to cumulative effects of forest management and climate change as evidenced from local knowledge. Journal of Ethnobiology and Ethnomedicine 13:51.

Tannerfeldt, M., B. Elmhagen, and A. Angerbjörn. 2002. Exclusion by interference competition? The relationship between red and arctic foxes. Oecologia 132:213-220.

Tapper, S., and J. Reynolds. 1996. The wild fur trade: historical and ecological perspectives. Pages 28-44 in V. J. Taylor, and N. Dunstone, editors. The exploitation of mammal populations. Springer, Dordrecht, South Holland, Netherlands.

Taylor, S. L., and S. W. Buskirk. 1994. Forest microenvironments and resting energetics of the American marten Martes americana. Ecography 17:249-256.

Titeux, N., K. Henle, J.-B. Mihoub, A. Regos, I. R. Geijzendorffer, W. Cramer, P. H. Verburg, and L. Brotons. 2016. Biodiversity scenarios neglect future land-use changes. Global Change Biology 22:2505-2515.

Vaillancourt, M.-A., P. Drapeau, S. Gauthier, and M. Robert. 2008. Availability of standing trees for large cavity-nesting birds in the eastern boreal forest of Québec, Canada. Forest Ecology and Management 255:2272-2285. 
41 | Suffice et al.

909 Weir, R. D., and P. L. Almuedo. 2010. British Columbia's interior: fisher wildlife habitat 910 decision aid. BC Journal of Ecosystems and Management 10(3):35-41.

911 Wengert, G. M., M. W. Gabriel, S. M. Matthews, J. M. Higley, R. A. Sweitzer, C. M.

912 Thompson, K. L. Purcell, R. H. Barrett, L. W. Woods, R. E. Green, et al. 2014.

913 Using DNA to describe and quantify interspecific killing of fishers in California.

$914 \quad$ Journal of Wildlife Management 78:603-611.

915 Whiteman, J. P., and S. W. Buskirk. 2013. Footload influences wildlife use of compacted

916 trails in the snow. Wildlife Biology 19:156-164.

917 Williams, B. W., J. H. Gilbert, and P. A. Zollner. 2007. Historical perspective on the

918 reintroduction of the fisher and American marten in Michigan and Wisconsin.

919 General Technical Report NRS-5. U.S. Department of Agriculture, Forest Service,

920 Northern Research Station, Newtown Square, Pennsylvania, USA.

921 Williams, C. M., H. A. L. Henry, and B. J. Sinclair. 2015. Cold truths: how winter drives

922 responses of terrestrial organisms to climate change. Biological Reviews 90:214-

923235

924 Zielinski, W. J., J. R. Dunk, and A. N. Gray. 2012. Estimating habitat value using forest

925 inventory data: the fisher (Martes pennanti) in northwestern California. Forest

926 Ecology and Management 275:35-42.

927 Zielinski, W. J., J. M. Tucker, and K. M. Rennie. 2017. Niche overlap of competing

928 carnivores across climatic gradients and the conservation implications of climate

929 change at geographic range margins. Biological Conservation 209:533-545.

930 Associate Editor: Grant Hilderbrand. 
42 | Suffice et al.

\section{Figure Captions}

932 Figure 1. Average yields (number of pelts sold/100 $\mathrm{km}^{2}$ ) per year for fisher (top) and

933 marten (bottom) according to fur-bearing animal management unit (FAMU) in Quebec,

934 Canada, between the 1984-1985 and 2014-2015 trapping seasons. Hatched areas

935 represent the 3 zones separated according to forest logging intensity, from the least

936 intensive in the south to the most intensive in the north. The map was constructed with

937 the program Nødebo in QGIS 2.160 (https://www.qgis.org/en/site/, accessed $21 \mathrm{Jul}$

938 2019), using North American Datum of 1983 (NAD 83)-Quebec Lambert projection

939 (European Petroleum Survey Group: 32198). 
43 | Suffice et al.

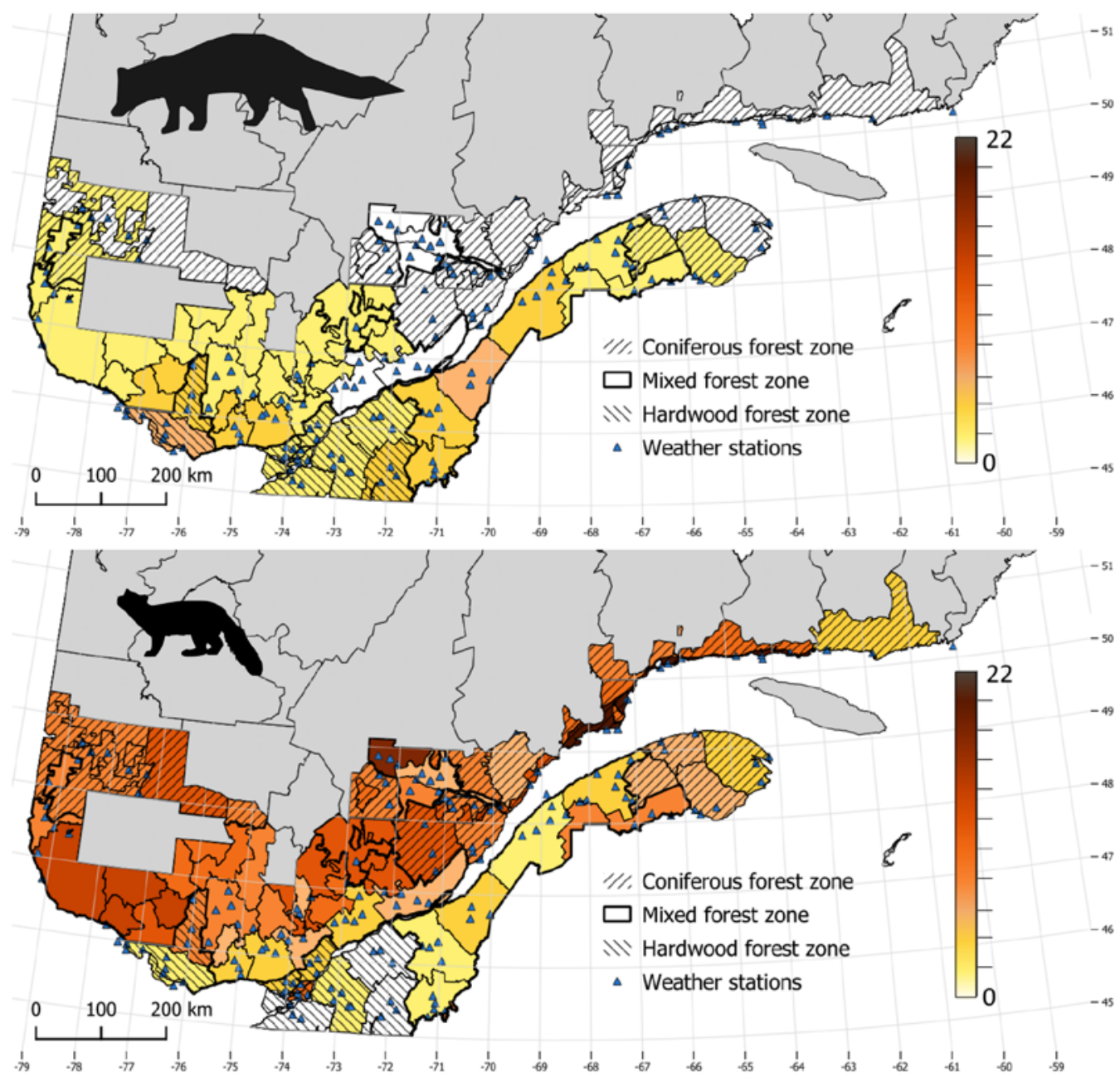


44 | Suffice et al.

942 Figure 2. Annual variation in fisher (left) and marten (right) yields according to fur-

943 bearing animal management unit (FAMU) in Quebec, Canada, 1984-2015, for the

944 coniferous (top), mixed (center), and hardwood (bottom) forest zones. Boxes represent

945 the first and third quartiles (interquartile distance), and the horizontal line within the box

946 is the median. Lower and upper whiskers represent scores outside the middle 50\%. Open

947 circles are outliers beyond 1.5 times the interquartile distance.
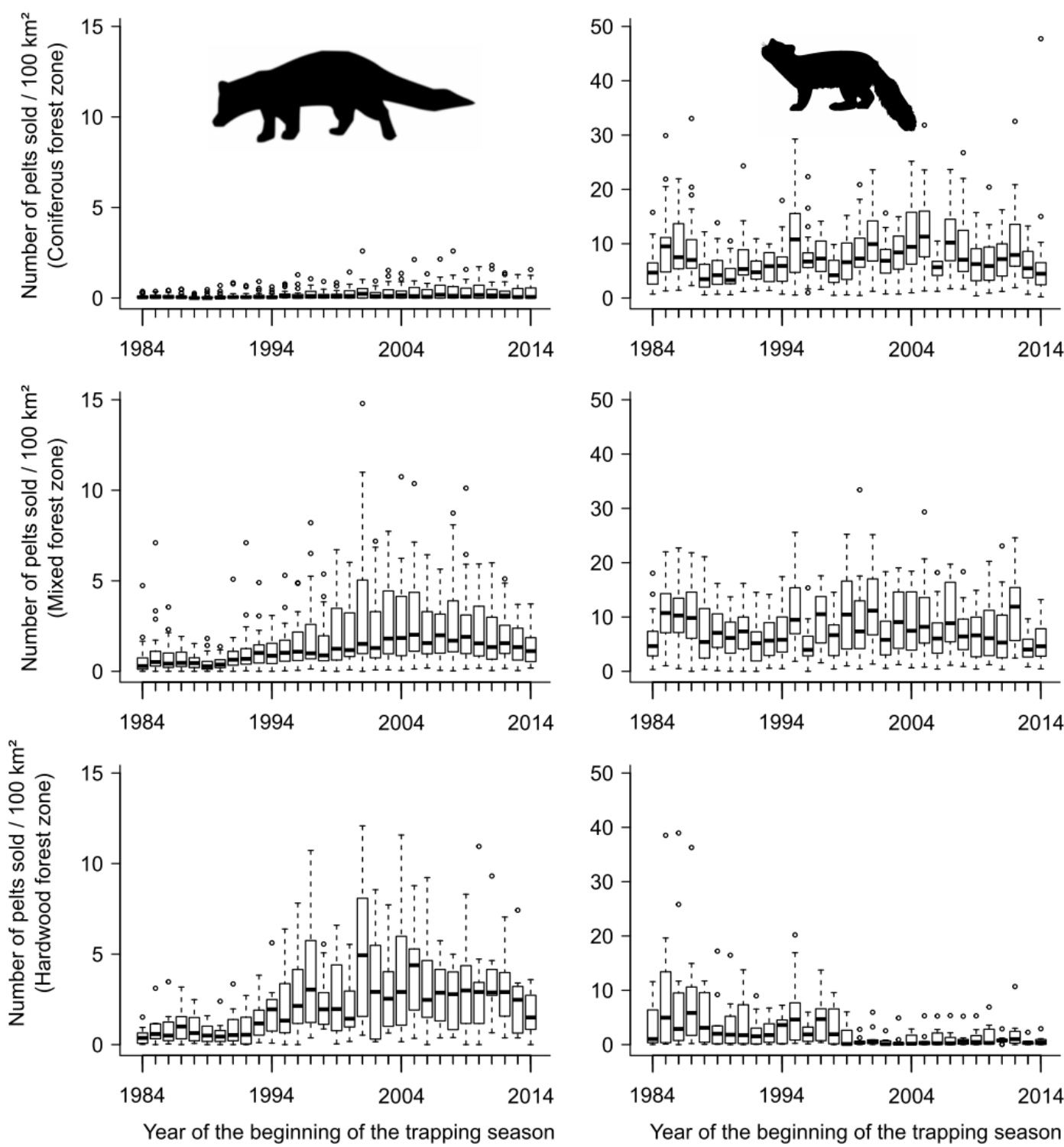
45 | Suffice et al.

949 Figure 3. Effect of year on fisher (left) and marten yields (right) predicted from multi-

950 model inference for each forest zone (hardwood, mixed, coniferous) of Quebec, Canada,

951 1984-2015. Black lines denote estimates; dotted lines represent unconditional 95\%

952 confidence intervals. Note that axes are not at the same scale but reflect differences in

953 yield between forest zones for the 2 species.
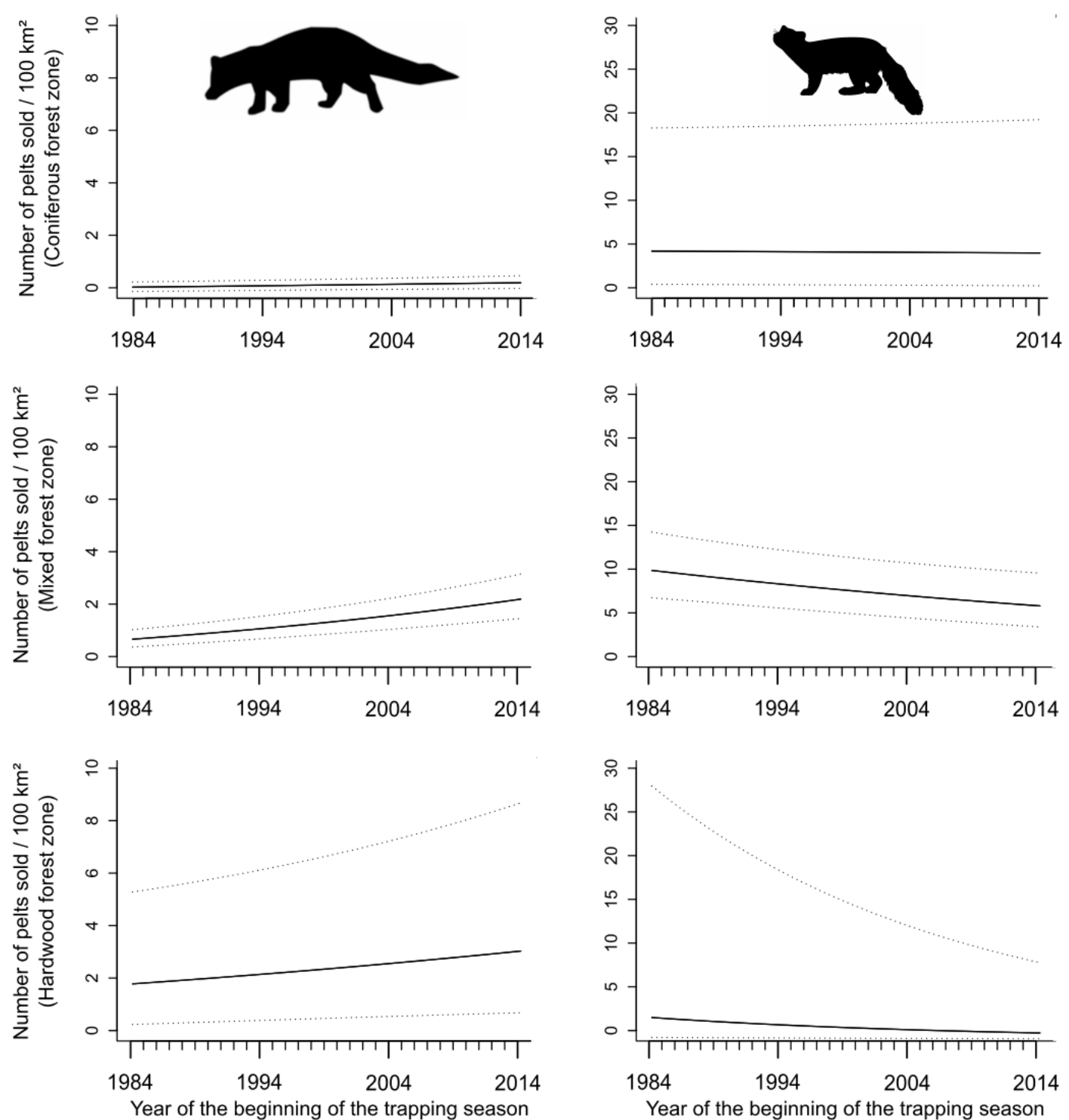
46 | Suffice et al.

955 Figure 4. Predicted fisher yield as a function of the fur-bearing animal management unit 956 percentage of deciduous (top) and mixedwood (bottom) stands $>12 \mathrm{~m}$ in the hardwood 957 forest zone (HFZ, left) and the coniferous forest zone (CFZ, right) of Quebec, Canada, 958 1984-2015. Black lines are estimates; dotted lines represent unconditional 95\%

959 confidence intervals.
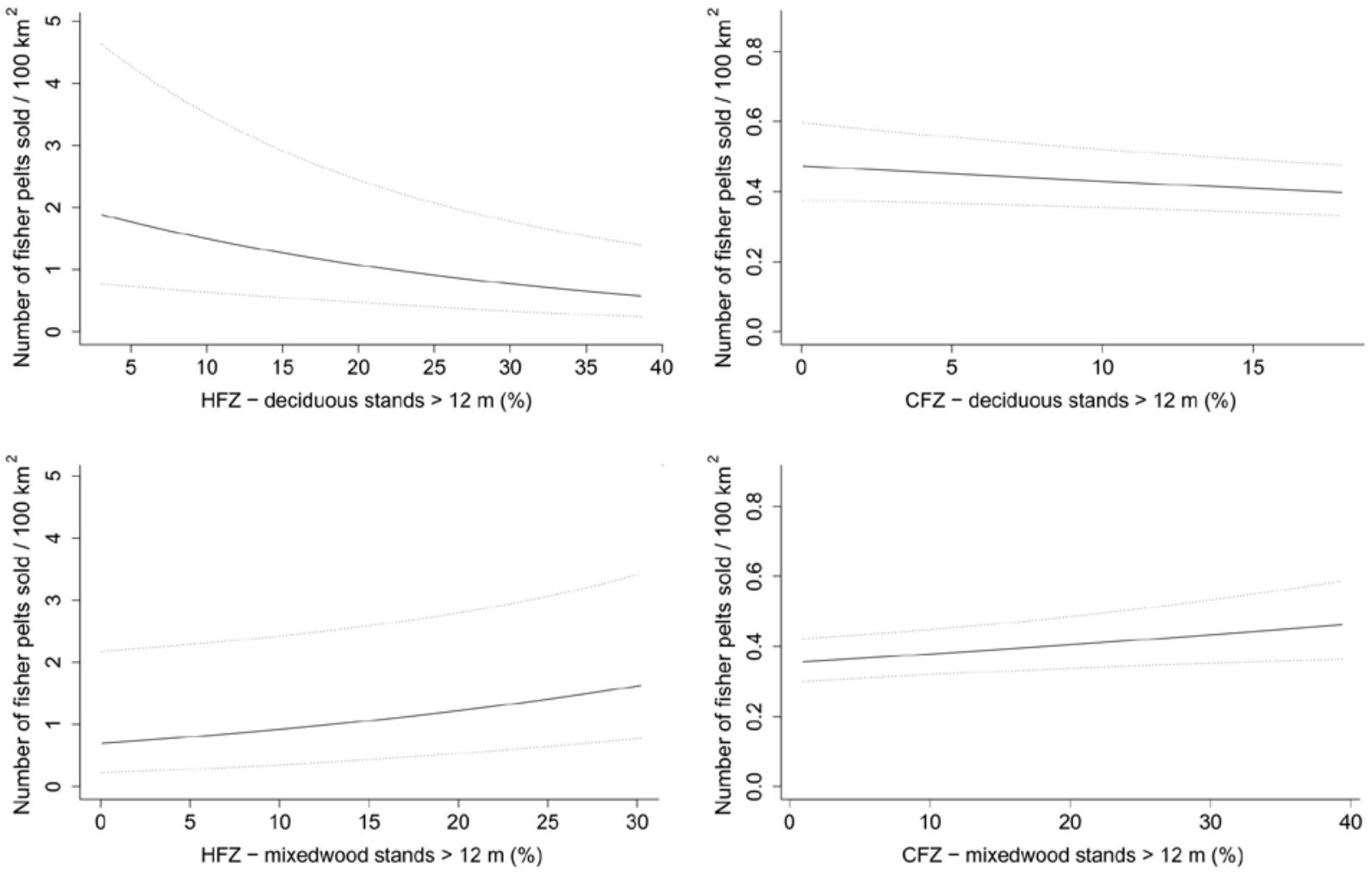
47 | Suffice et al.

962 Figure 5. Predicted marten yield as a function of the percentage of agricultural fields in

963 fur-bearing animal management units of the mixed forest zone (MFZ) of Quebec,

964 Canada, 1984-2015. The black line is the estimate; dotted lines represent unconditional $96595 \%$ confidence intervals.

966

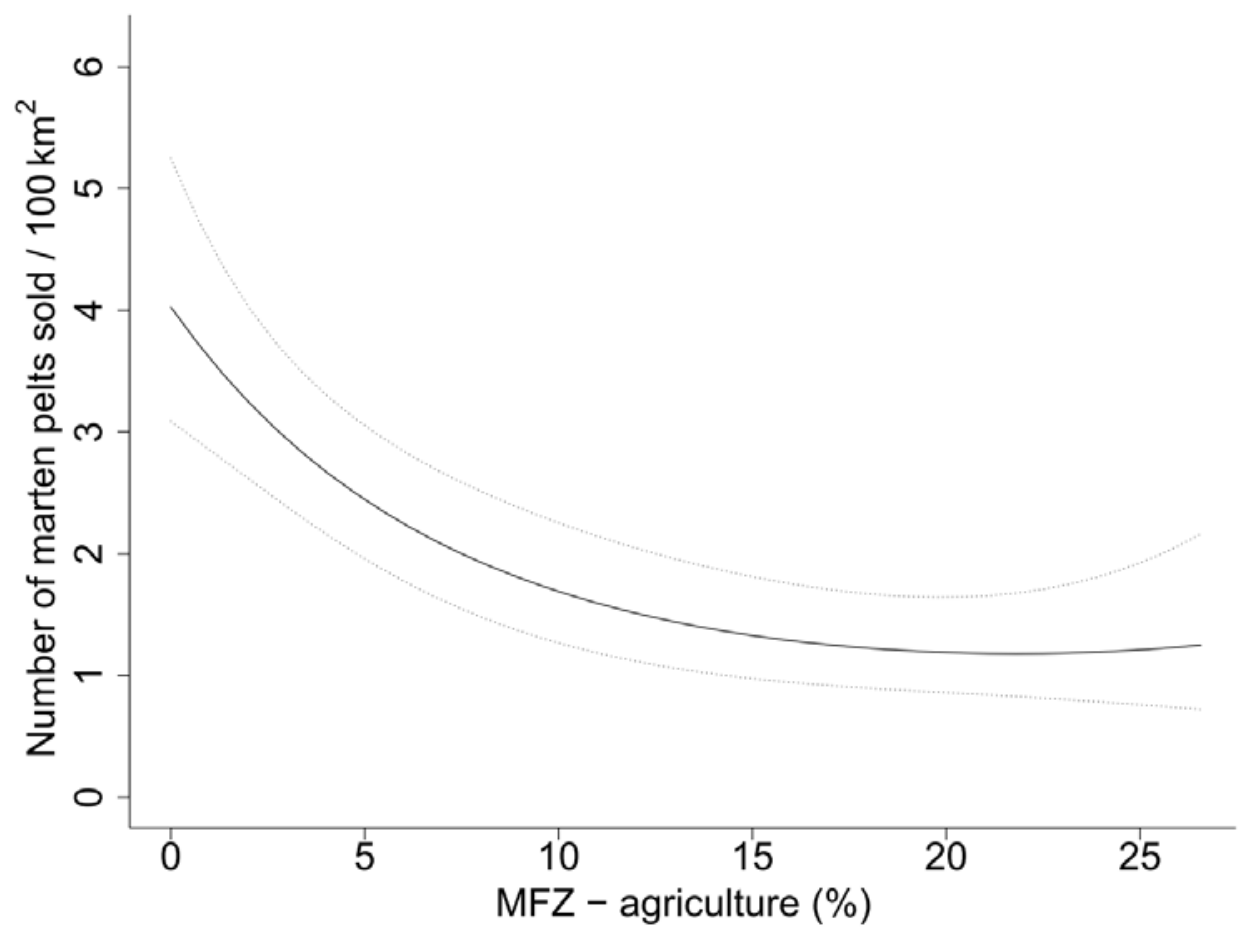


48 | Suffice et al.

968 Figure 6. Predicted marten yield as a function of the number of days with rain (top) and

969 amount of rain (bottom) that fell in the winter preceding the trapping season in the mixed

970 forest zone (MFZ) of Quebec, Canada, 1984-2015. The black line is the estimate; dotted

971 lines represent unconditional 95\% confidence intervals.
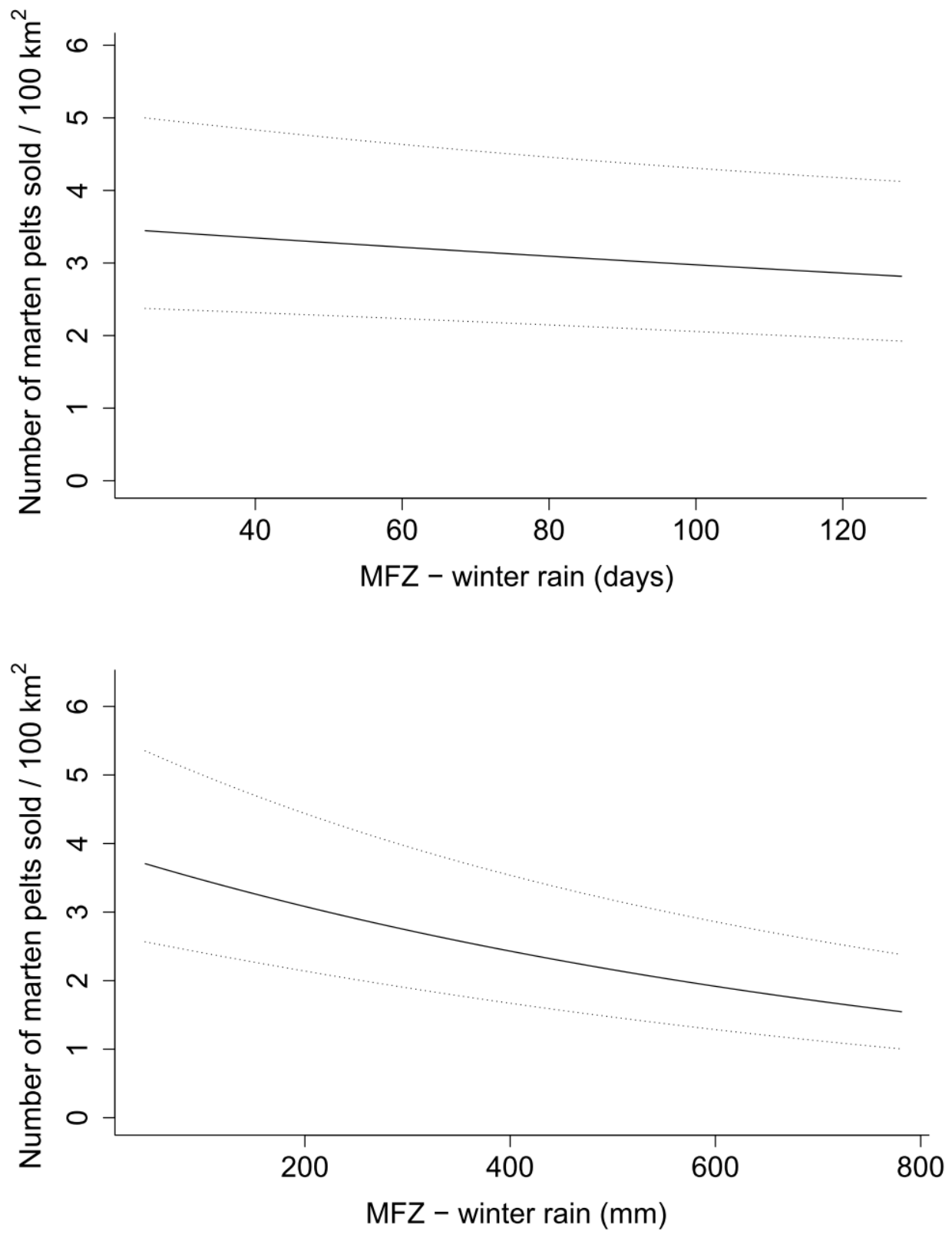

972

973 
49 | Suffice et al.

974 Figure 7. Predicted marten yield as a function of the amount of rain that fell during the

975 trapping season in the coniferous forest zone (CFZ) of Quebec, Canada, 1984-2015. The

976 black line is the estimate; dotted lines represent unconditional 95\% confidence intervals.

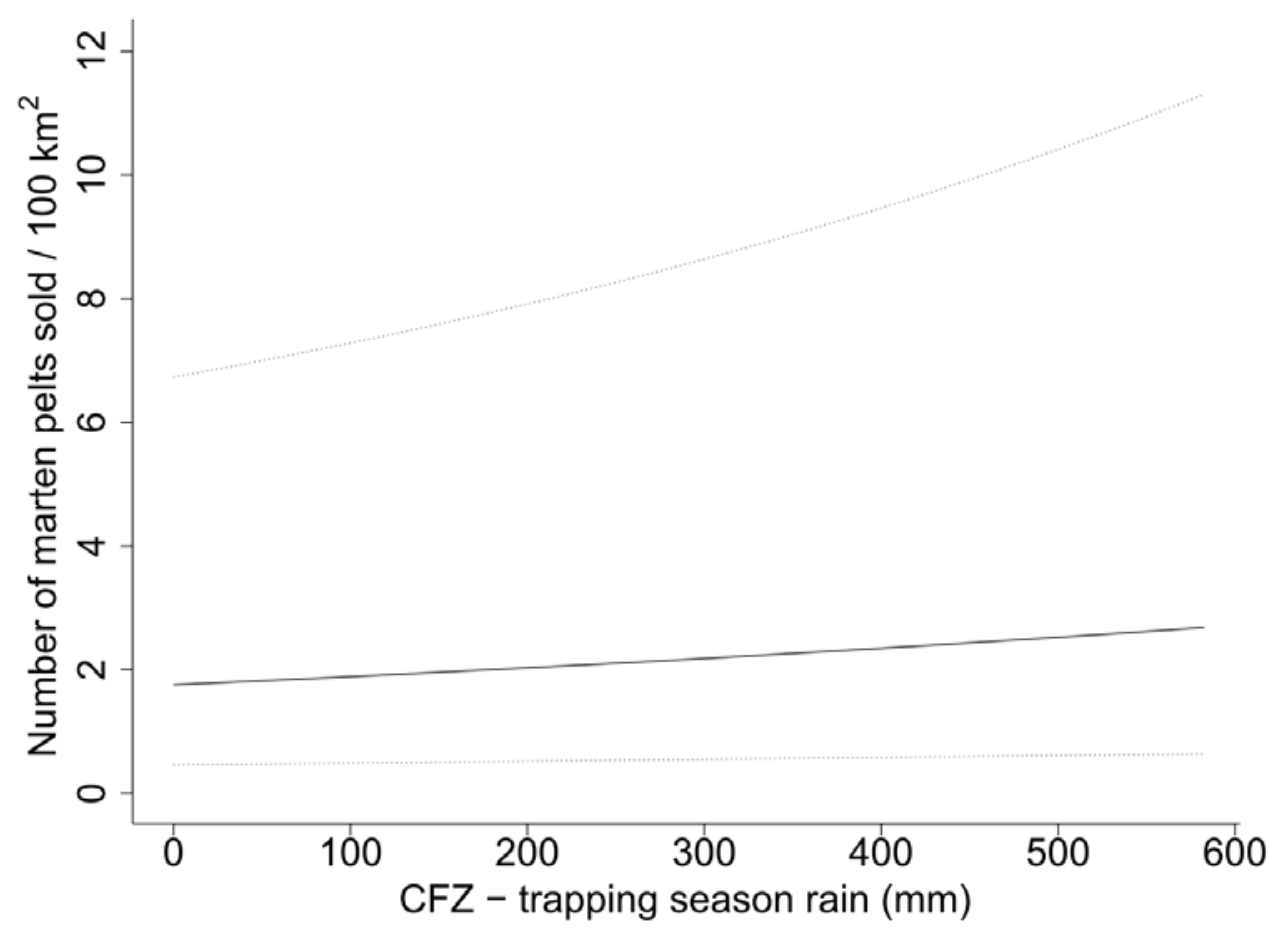


980 (Suffice et al. 2017).

Hypothesis
Trappers capture more fishers but fewer martens
over time (Poulin et al. 2006, Suffice et al. 2017).
Number of captures increases with trapping effort
and pelt price from previous year.

Fishers can use younger and more open forests than the old stands described in the literature (Suffice et al. 2017). Lack of important predators (such as cougar or bobcat) in the northern part of its range in Quebec could explain the use of open areas by fisher (Wengert et al. 2014). Martens depend on a dense canopy offering protection against predation and inclement weather. Forests with trees $<12 \mathrm{~m}$ in height do not have these characteristics.

Fishers need large trees used as refuge and to raise young; such trees are found in older forests, which can also provide protective cover by intercepting snow (Aubry et al. 2013). The structural complexity of older forests increases the availability of prey dependent on dead wood (small mammals; Fauteux et al. 2012) and a dense cover

\begin{tabular}{llll} 
Model & Explanatory variables & $\begin{array}{l}\text { Predicted } \\
\text { fisher response }\end{array}$ & $\begin{array}{l}\text { Predicted } \\
\text { marten response }\end{array}$ \\
\hline Null & Year + (year | FAMU) & + & - \\
& + number of trappers & + & + \\
& + marten pelt price from & + & + \\
& previous year & & \\
Stands 4-12 & Deciduous 4-12 m cover & + & - \\
m cover & + mixedwood 4-12 m cover & + & - \\
& + coniferous 4-12 m cover & + & - \\
& + null model & & \\
& & & \\
& & & \\
& & & \\
& & & \\
Stands $>12$ & Deciduous $>12 \mathrm{~m}$ cover & + & + \\
m cover & + mixedwood $>12 \mathrm{~m}$ cover & + & + \\
& + coniferous $>12 \mathrm{~m}$ cover & + & \\
& + null model &
\end{tabular}


(snowshoe hare; Fuller and Harrison 2013). Old coniferous stands are more amenable to a complex internal structure and a dense canopy on which marten depends (Cheveau et al. 2013). However, martens also use hardwood stands, as long as they are old and dense (Suffice et al. 2017).

In the absence of important predators, fishers can use more open areas such as agricultural fields (Suffice et al. 2017). The ecotone between forest and agricultural fields may offer a greater diversity of prey for fisher. However, more agricultural fields also means less forest on which fishers depend. Agricultural fields are open areas where marten could be more vulnerable to predation.

Fisher movements are limited in areas where snow is abundant. Crust increases snow lift and therefore the probability that a fisher can use a territory. More crust during the previous winter would favor fisher movements, survival and reproductive success. Marten use subnival environments to hunt and as protection against winter weather (Taylor and Buskirk 1994). Crust on the snowpack compromises subnival access (Berteaux et al. 2017).

Cold spring rainfall during the first few weeks of life of young mustelids can affect survival potential, and thus recruitment and number of captures by trappers the following year.

\section{Agriculture Agriculture cover \\ cover \\ $+{\text { (agriculture cover })^{2}}^{2}$ \\ + null model}

Rain during Number of rain days during previous previous winter

winter + rain amount during previous winter + null model

Cold rain Number of rain days during during previous spring previous + null model 
52 | Suffice et al.

Ice crust during the trapping season ( 15 Nov-1

Rain during
trapping

Number of rain days during

$+$

Mar) may favor fisher movements and increase the

likelihood of encountering a trap.

season

trapping season

+ rain amount during trapping +

+ null model

981

982 
53 | Suffice et al.

984 Table 2. Model-averaged estimates of variables for which the 95\% confidence interval excluded 0 ( $\beta$ i [lower confidence limit, upper

985 confidence limit]) in models explaining fisher yield per year per fur-bearing animal management unit in Quebec, Canada, $1984-2015$.

\begin{tabular}{|c|c|c|c|c|}
\hline Variable & $\begin{array}{l}\text { Predicted } \\
\text { response }\end{array}$ & $\begin{array}{l}\text { Hardwood forest } \\
\text { zone }\end{array}$ & $\begin{array}{l}\text { Mixed } \\
\text { forest zone }\end{array}$ & $\begin{array}{l}\text { Coniferous } \\
\text { forest zone }\end{array}$ \\
\hline Number of trappers in given year & + & $0.76[0.65,0.87]$ & $0.27[0.23,0.31]$ & $0.05[0.03,0.07]$ \\
\hline Pelt price of previous year & + & $-0.05[-0.09,-0.01]$ & $-0.04[-0.06,-0.02]$ & $-0.02[-0.02,-0.01]$ \\
\hline Deciduous 4-12 m cover & + & & & \\
\hline Mixedwood 4-12 m cover & + & & & \\
\hline Deciduous $>12 \mathrm{~m}$ cover & + & $-0.38[-0.60,-0.16]$ & & $-0.11[-0.20,-0.02]$ \\
\hline Mixedwood $>12 \mathrm{~m}$ cover & + & $0.31[0.04,0.56]$ & & $0.07[0.01,0.13]$ \\
\hline Coniferous $>12 \mathrm{~m}$ cover & + & & & \\
\hline Quadratic effect of agriculture cover & + & & & \\
\hline Number of rain days during previous winter & + & & & \\
\hline Rain amount during trapping season & + & & & \\
\hline
\end{tabular}


54 | Suffice et al.

Table 3. Model-averaged estimates of variables for which the $95 \%$ confidence interval excluded 0 ( $\beta$ i [lower confidence limit, upper

2015.

\begin{tabular}{|c|c|c|c|c|}
\hline Variable & Prediction & $\begin{array}{l}\text { Hardwood } \\
\text { forest zone }\end{array}$ & $\begin{array}{l}\text { Mixed } \\
\text { forest zone }\end{array}$ & $\begin{array}{l}\text { Coniferous } \\
\text { forest zone }\end{array}$ \\
\hline Year & - & $\begin{array}{l}-0.37[-0.52 \\
-0.21]\end{array}$ & $-0.14[-0.22,-0.05]$ & \\
\hline Number of trappers in given year & + & $0.45[0.27,0.63]$ & $0.65[0.58,0.71]$ & $0.67[0.60,0.70]$ \\
\hline Pelt price of previous year & + & & $-0.06[-0.09,-0.03]$ & $-0.05[-0.08,-0.02]$ \\
\hline Deciduous 4-12 m cover & - & & & \\
\hline Mixedwood 4-12 m cover & - & & & \\
\hline Coniferous $4-12 \mathrm{~m}$ cover & - & & & \\
\hline Deciduous $>12 \mathrm{~m}$ cover & + & & & \\
\hline Mixedwood $>12 \mathrm{~m}$ cover & + & & & \\
\hline Coniferous $>12 \mathrm{~m}$ cover & + & & & \\
\hline Quadratic effect of agriculture cover & - & & $0.51[0.02,0.99]$ & \\
\hline Number of rain days during previous winter & - & & $-0.03[-0.06,0]$ & \\
\hline Rain amount during previous winter & - & & $-0.09[-0.12,-0.06]$ & \\
\hline Number of cold rain days during previous spring & - & & & \\
\hline Number of rain days during trapping season & + & & & \\
\hline Rain amount during trapping season & + & & & $0.04[0.01,0.08]$ \\
\hline
\end{tabular}


55 | Suffice et al.

\section{Summary for online Table of Contents}

991 In areas where fisher and marten habitats overlap in Quebec, Canada, fishers benefit from

992 increased abundance of mixedwood forests taller than $12 \mathrm{~m}$, whereas martens are

993 negatively affected by increased rainfall in winter. Results of this study support

994 hypotheses made by local trappers about fisher and marten habitat use. Managers should

995 strive to maintain mixedwood stands taller than $12 \mathrm{~m}$ to maintain habitat for fishers. 
56 | Suffice et al.

\section{APPENDIX A. FISHER MODEL SELECTION}

997 Table A1. Selection based on the Akaike's Information Criterion for small samples

$998 \quad\left(\mathrm{AIC}_{c}\right)$ among linear mixed models explaining fisher yields in Quebec, Canada, 1984-

999 2015. All models included a random intercept and a random slope of year for each fur-

1000 bearing animal management unit, a continuous first-order autocorrelation structure, and

1001 fixed effects for the number of trappers who sold $\geq 1$ marten or fisher pelt and marten pelt

1002 price of the previous year. We present the number of model parameters $(K)$, difference in

$1003 \mathrm{AIC}_{c}$ between the top-ranked model and other candidate models $(\triangle \mathrm{AIC} c)$, Akaike weight

$1004\left(\omega_{\mathrm{i}}\right)$, and log-likelihood (LL). Only models with $\Delta \mathrm{AIC}_{c}<4$ are presented.

\begin{tabular}{|c|c|c|c|c|c|c|}
\hline Zone & Fisher model & $K$ & $\mathrm{AIC}_{c}$ & $\Delta \mathrm{AIC}_{c}$ & $\omega_{\mathrm{i}}$ & LL \\
\hline \multirow[t]{3}{*}{$\begin{array}{l}\text { Hardwood } \\
\text { forest }\end{array}$} & $\begin{array}{l}\text { Stands }>12 \mathrm{~m} \text { cover }+ \text { rain during } \\
\text { previous winter }\end{array}$ & 14 & 62.62 & 0.00 & 0.62 & -16.59 \\
\hline & $\begin{array}{l}\text { Stands }>12 \mathrm{~m} \text { cover }+ \\
\text { cold rain during previous spring }\end{array}$ & 13 & 64.54 & 1.92 & 0.24 & -18.64 \\
\hline & $\begin{array}{l}\text { Stands }>12 \text { m cover }+ \text { rain during } \\
\text { trapping season }\end{array}$ & 14 & 66.43 & 3.81 & 0.09 & -18.49 \\
\hline \multirow{4}{*}{$\begin{array}{l}\text { Mixed } \\
\text { forest }\end{array}$} & Cold rain during previous spring & 10 & -266.20 & 0.00 & 0.46 & 143.21 \\
\hline & $\begin{array}{l}\text { Agriculture cover }+ \text { cold rain } \\
\text { during previous spring }\end{array}$ & 12 & -264.90 & 1.30 & 0.24 & 144.61 \\
\hline & $\begin{array}{l}\text { Stands } 4-12 \text { m cover }+ \text { cold rain } \\
\text { during previous spring }\end{array}$ & 13 & -263.32 & 2.89 & 0.11 & 144.84 \\
\hline & $\begin{array}{l}\text { Stands }>12 \text { m cover }+ \text { cold rain } \\
\text { during previous spring }\end{array}$ & 13 & -262.96 & 3.24 & 0.09 & 144.67 \\
\hline $\begin{array}{l}\text { Coniferous } \\
\text { forest }\end{array}$ & $\begin{array}{l}\text { Stands }>12 \text { m cover }+ \text { cold rain } \\
\text { during previous spring }\end{array}$ & 13 & -1338.44 & 0.00 & 0.84 & 682.47 \\
\hline
\end{tabular}


57 | Suffice et al.

\section{APPENDIX B. MARTEN MODEL SELECTION}

1008 Table B1. Selection based on the Akaike's Information Criterion for small samples

$1009\left(\mathrm{AIC}_{c}\right)$ among linear mixed models explaining marten yields in Quebec, Canada, 1984-

1010 2015. All models included a random intercept and a random slope of year for each fur-

1011 bearing animal management unit, a continuous first-order autocorrelation structure, and

1012 fixed effects for the number of trappers who sold $\geq 1$ marten or fisher pelt and marten pelt

1013 price of the previous year. We present the number of model parameters $(K)$, difference in

$1014 \mathrm{AIC}_{c}$ between the top-ranked model and other candidate models $\left(\Delta \mathrm{AIC}_{c}\right)$, Akaike weight

$1015\left(\omega_{\mathrm{i}}\right)$, and log-likelihood (LL). Only models with $\Delta \mathrm{AIC}_{c}<4$ are presented.

\begin{tabular}{|c|c|c|c|c|c|c|}
\hline Zone & Marten model & $K$ & $\mathrm{AIC}_{c}$ & $\Delta \mathrm{AIC}_{c}$ & $\omega_{\mathrm{i}}$ & LL \\
\hline Hardwood & Null & 9 & 438.00 & 0.00 & 0.25 & -209.69 \\
\hline \multirow[t]{6}{*}{ forest } & $\begin{array}{l}\text { Cold rain during previous } \\
\text { spring }\end{array}$ & 10 & 438.50 & 0.50 & 0.19 & -208.88 \\
\hline & Stands $4-12 \mathrm{~m}$ cover & 12 & 438.93 & 0.94 & 0.16 & -206.93 \\
\hline & $\begin{array}{l}\text { Stands } 4-12 \text { m cover }+ \text { cold } \\
\text { rain during previous spring }\end{array}$ & 13 & 439.78 & 1.78 & 0.10 & -206.26 \\
\hline & Stands $>12 \mathrm{~m}$ cover & 12 & 441.23 & 3.23 & 0.05 & -208.08 \\
\hline & Agriculture cover & 11 & 441.61 & 3.61 & 0.04 & -209.35 \\
\hline & Rain during previous winter & 11 & 441.63 & 3.63 & 0.04 & -209.36 \\
\hline Mixed forest & $\begin{array}{l}\text { Agriculture cover }+ \text { rain } \\
\text { during previous winter }\end{array}$ & 13 & 749.98 & 0.00 & 1 & -361.81 \\
\hline \multirow[t]{3}{*}{$\begin{array}{l}\text { Coniferous } \\
\text { forest }\end{array}$} & $\begin{array}{l}\text { Stands } 4-12 \mathrm{~m} \text { cover }+ \text { rain } \\
\text { during trapping season }\end{array}$ & 14 & 588.61 & 0.00 & 0.57 & -280.02 \\
\hline & $\begin{array}{l}\text { Rain during trapping } \\
\text { season }\end{array}$ & 11 & 591.55 & 2.94 & 0.13 & -284.60 \\
\hline & $\begin{array}{l}\text { Agriculture cover }+ \text { rain } \\
\text { during trapping season }\end{array}$ & 13 & 591.70 & 3.08 & 0.12 & -282.60 \\
\hline
\end{tabular}

